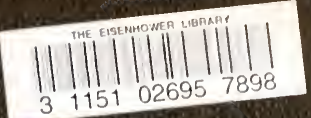

s

MORAHA

SPE foll 


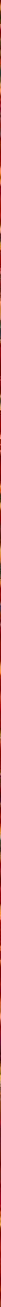
n้⿵⺆⿻二丨 A. $A$ alais 2"A"/ $/ 6$ a 1 ก "A ล N dilurity (n) (2) A . . ลิ 2 A. Niñ a

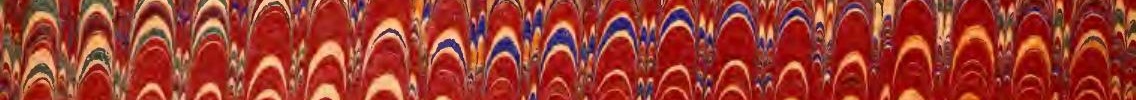

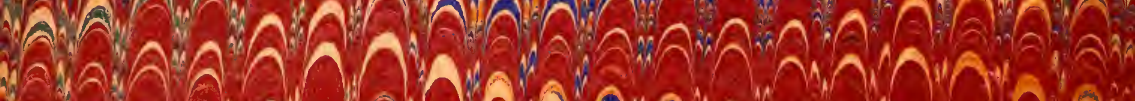
A - 


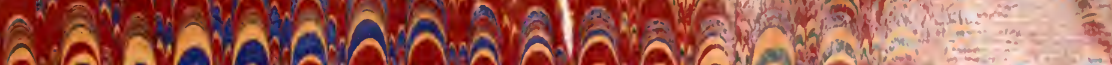
2. Nhwn:

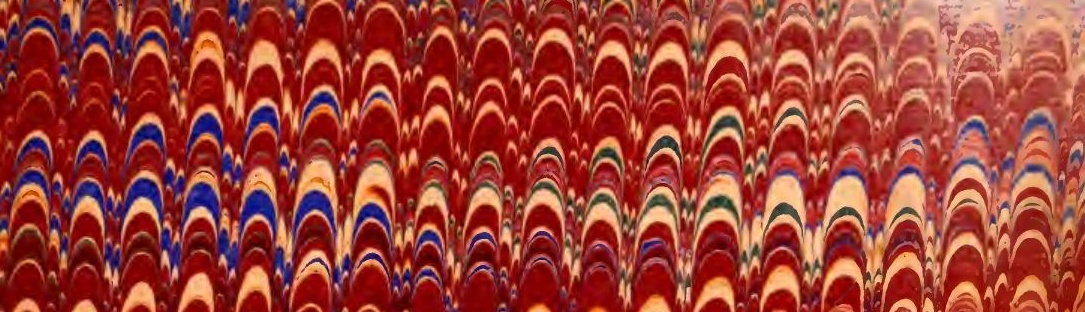

A A A W'A

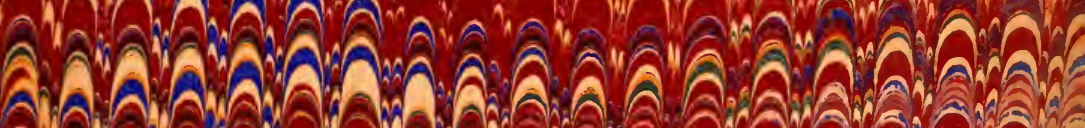
(6)

(1)

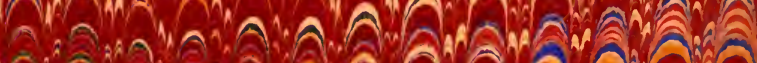

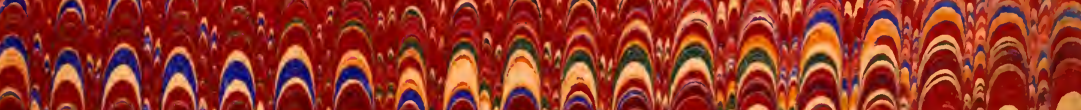

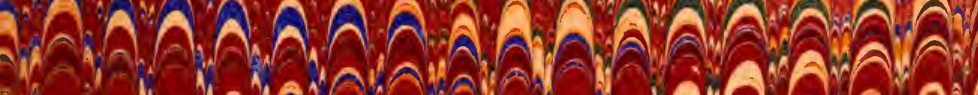

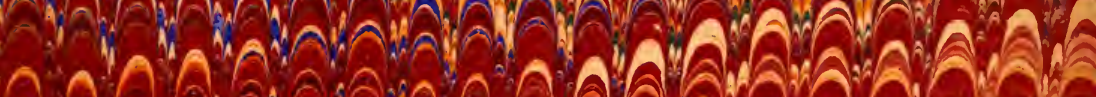
:

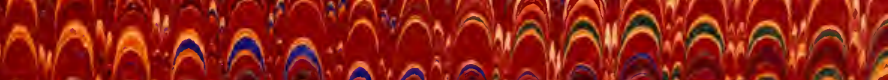

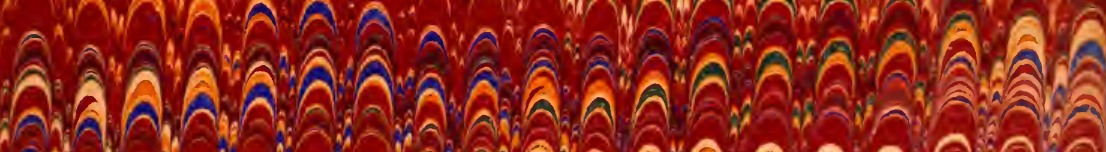
L 2.

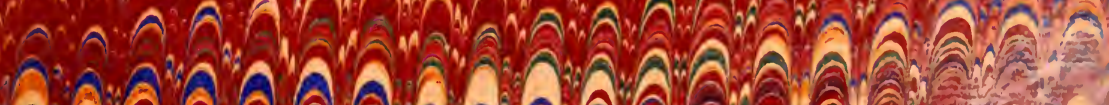

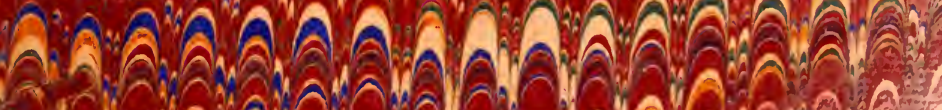

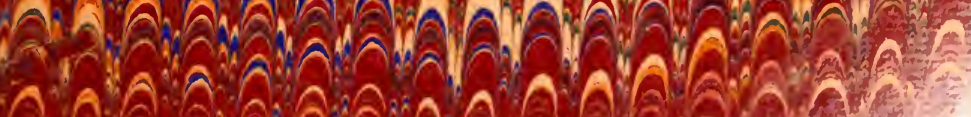





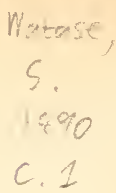




$$
\begin{aligned}
& \text { (an the Mlophilogy of the } \\
& \text { (impr...c 2, to o } \\
& \text { Astapelos. } \\
& \text { S. Batare. } \\
& \text { Bunce "Filen in Biology }
\end{aligned}
$$

Prementic ax a The is to of tain

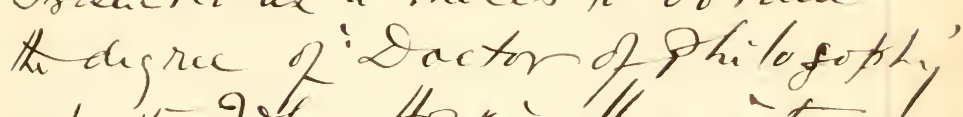

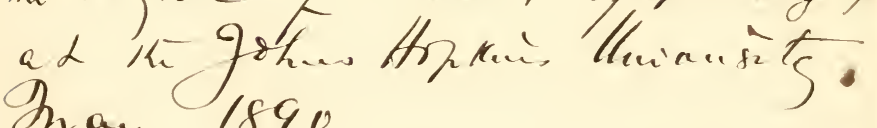
Mray 1890 . 
Bity 17? 


\section{ON THE MORPHOLOGY OF THE COMPOUND}

EYES OF ARTHROPODS. By S. WATASE, Fellow of the Johns Hopkins University. With Plates XXIX-XXXV.

Contents.
I. Introduction $\ldots \ldots \ldots \ldots \ldots \ldots \ldots \ldots \ldots \ldots \ldots \ldots \ldots \ldots \ldots \ldots \ldots$
287

II. Morphology of the Ommatidium.

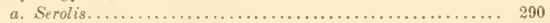

b. Talorcheslia................................ 295

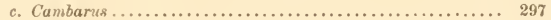

d. Homarus.... . ............................ 299

e. Callinectes.................................. 299

III. Compound (Lateral) Eye of Limulus.

a. General sketch of the Compound Eye................ 301

b. Structure of the Ommatidium .................... 302

c. Derelopment of the Compound Eye ................. 307

IV. Phylogeny of the Ommatidium ..................... 313

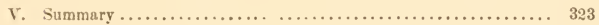

VI. Appendix: The Compound Eye of Echinoderms ............ 324

VII. Explanation of Figures $\ldots \ldots \ldots \ldots \ldots \ldots \ldots \ldots \ldots \ldots \ldots \ldots \ldots \ldots \ldots \ldots \ldots \ldots \ldots \ldots \ldots+334$

\section{I.-Introduction.}

Early in the spring of 1 sss, Prof. W. K. Brooks kindly placed at my disposal a valuable set of specimens of Limulus, ${ }^{1}$ with a suggestion that I should work on the eves in order to eontinue the research upon which the late Dr. A. T. Bruee was engaged at the time of his death.

Through the kindness of Prof. M. McDonald, the United States Commissioner of Fish and Fisheries, I was enabled to continue my work on the subject during the summer of the same year at the Woods Holl Laboratory of the Fish Commission, where the fresh specimens for the study of Limulus at all stages of development may be obtained without difficulty. To these gentlemen are due my sincere thanks and gratitude; through their kindness and encouragement I lave been enabled to prosecute my

${ }^{1}$ These specimens were inostly preserved by Dr. J.C. Memmeter, when the Chesapeake Znological Lahoratory was in session at Beaufort, N. C., in 1885. They were in an excellent state of preservation. 

work. I am also indebted to I'rof'. Joln A. Lyder and Dr. E. A. Andrews for rarious courtesies.

It soon became evident that the eye of Limulus is, as wo might expect from its great antiquity, a very primitive visual organ, presenting in a simple form a most interesting type.

For the further comprehension of its structure and siguificanee it becume necessary to extend my researches to several other Arthropols. Among the forms sturlied in this eonnection are the following, besides five other pelagic Arthropods from the Gulf Stream, whose generic names have not yet been ascertained: Branchipus, Estheria, Talorchestia, Iyperia, Phromima, Serolis, Ligia, Asellus, Wotonectu, Libellula, Agron, Gryllus, Corethra, C'ambarus, Homurus, Ilippa, Ilpheus, Gehia, I'enaeus, squilla, Cullinectes, Gonolactylus and Lucifer.

While only a few selected types are here described, all the abose named forms, representing three great groups of $\mathrm{Arthro-}$ pods, Inseets, Crustacea and Arachnids, were earefully studied, and all the results have been embodied in the general observations which follow, althongh the prineipal subject of the paper is the eye of Limulus.

The points which are at present receiving marked attention among the workers on the morphology of the componnd eyes of Arthropods may be put in fonr principal categrories, viz. (1) the mode of termination of the optic nerve fibre in the retinal cell; (2) the inode of formation of different "layers" in the retina; (3) the phylogeny of the eomponnd eye; and (4) the homology of the optie ganglia.

The problem therefore involves several inquiries. The fundamental step is to determine to what morphological eategory the compound eye of the Arthropod belongs. To the elucidation of this point our histologieal inquiries mnst be directerl, while our phylogenetic consideration of the eye may fitly be reserved nutil we have learned something of its structure.

The first thing which confronts $n \mathrm{~s}$ is this: What is the ommatidium or "eyelet," the repetition of which, often several thousandfold, gives rise to the eompound eye? What is the significance of the eharacteristic arrangement of its component cells? Is it possible to reduce it to a simpler form, or to express its structure and significanee briefly? 

Intil these questions be suswerch antistactorily, the nost lahorions terhnique of histology is often powerless to discriminte the essential from the secondary features in the component cells of a given ommatidium: and in the absenee of an acrorate conception of its findamental strueture, the various morlifications of the cells and fibres of an ommatidiun may be made to assmme any simniliemce to snit our speenlative ideas.

With these eonsiderations in mind, I have songht for an ommatidium in which all the features of its structural elenents may be made out plainly, and from which we may derive the ommatidial elements of a more complex type.

Although the number of forms studied in this connection is not quite so extensive as I wish, I feel justified in believing that any view which explains the structural peculiarities of the ommatidia of each and all of the forms in the list above given and reduces them to the same fundamental structure, may fairly - be considered as in all probability generally applieable to the eyes of Artliropods.

In what follows, the attempt will be made to approach the subject from this standpoint, viz. the consideration of the ommatidiun as the morphological unit of the compound eye in Arthropork, just as each little cirele of rods with a cone in its eentre may be eonsidered as the morpholoyical unit of the "mosaic layer" (Henle) of the human retina.

\section{II.-Tue Morpiology of the Omatidium.}

Following the plan given in the Introduction, I will eonsider the morphology of the ommatidium, taking it as the structural unit of the eompound eye. After the nature of this mit has been considered, we may proceed to examine the state of aggregation of the units in the different forms of the $\Delta$ rthropods. For this purpose it is convenient to select one partieular ommatidium which may be made the basis of emparison. Accorlingly, the ommatidium of verolis will be considered at the ontset, and the at tempt will be made to homologize the ommatidial elements of Serolis with those of other fums. I an indebted to l'rof. M. MeDonald for the opportunity to study the eyes of the four Sonth Anerican forms of Serolis reeently brought back by the U.S. Fish Commission steamer Albatross. 



$$
\text { a. Serolis. }
$$

(Figs, 1, $1 a, 1 b, 2,1$ l'. XXIX.

The general structure of the eyes of Sirmlis has already been made known by Beddard.' Althomgh I have verifiel all the ehicf results of his research, I slunll spenk of a tew details which seen to me specially signifieant.

The cells of the ommatidinm are arranged in three prineipal strata, $t, b, c$ (Fig. 1a, Pl. XXIX). Each stratum of cells is eharacterized by the special produet which it secretes, viz. 1, 2 and 3.

The ontermost stratum $(a)$ secretes upon its external snrface the ehitin which constitntes the comea or the corneal fact $(c$, Fig. 1, Pl. XXIX).

The cells themselves have been designated as the cornerigen by Patten.?

The corneagen is sometimes difficult to detect in the eye of the adnlt animal and may easily be overlooked. It is very conspicnons in the young.

The next stratum of cells $(b)$ is also characterized by the ehitinons secretion on the surface nearest the median axis of the ommatidium. The two cells $(b)$ secrete a thick chitinous layer which encloses an ovoidal space of considerable size filled with a transparent liquid substance, $(2)$. The cell (b) has leen named vitrella (Lankester and Bonrne): $:^{3}$ and the ovoidal chitinons body. (2) is the crystalline cone $e^{4}$ (c.e, Fig. 1, Pl. XXIX.)

${ }^{1}$ Beddard, F. E. Challenger Report, Zoology. Vol. XI, Isopoda: Serolidae. His additional observations on Serolis may be found in tho paper by the sume author, On the Minute Structure of the Eye in Cymothoidae. Trans. Roy. Soc. Edin. $188 \%$.

- Sludies on the Eyns of Arthropod: I. Development of the Eyes of Vespa, with observations on the Ocelli of some Insects, p. 193, Journal of Morphology, Vol. 1, No. 1, 1887.

The Minute Structure of the Lateral and the Central Eyes of Scorpio and Limulus. Quart. Jour. of Miero. Seience, Vol. XXIll, p. 198, 1883.

"Vitrella" is syuonymons with " retiuophora" of Putten: "vitreous cell " and "erystalline cone eell" of authors. The nucleus of the vitrella lus been named by Claparcde "Semprer's nucleus," aftet its discoverer : Zur Morphologie der zusummengesetzten Augen bei den Arthropoden. Von Elouard Claparèdo. Zeit. f. Wiss. Zool. Bd. X, p. 193, 1460.

4 It is interesting to notice that the observations made by Clarke on the eye of a Trilobite (The Structure and Development of the Visual Area in the Trilobile, 

The erystalline eone is purely a dioptric apparatus. A eareful study of its structure, both in the adnlt and in the young embryos of Serolis, has clearly shown that this has nothing to do with the sensory function, as it hat no connection whatever with the optic nerve fibres.

The ritrella, then, agrees with the corneagen eell in the eapacity for secreting chitin on one portion of its surface. The difference between them consist: in this, that while the corneagen cells secrete chitin towards the exterior of the borly, the vitrellae secrete it towarls each other, that is, towards the median axis of the ommatidium.

Next below the vitrella comes the important stratum (e, Fig. 1 $\iota$ ) which lies at the bottom of the whole structure, and which sends processes inward $(1) p, n$ ) to form the optic nerve fibre, which terminates in the optic ganglion.

The eells in this structure are also characterized by secreting chitin towards the median axis of the ommatidinm. The chitin thus produced invests the colorless portion of the eell $(c)$ constituting the rod or the rhabdomere (Lankester aud Bourne). ${ }^{1}$

$\Lambda$ large number of transverse striae, running at right angles to the longitudinal axis of the ommatidium, are seen through the transparent entiele. The eell itself which gives rise to the rhabdomere has been known as retinula (Grenacher). ${ }^{2}$ The

Phacops Rana, Green, Journal of Morphology, Vol. I1, No. 2, 1848) show, so fur as I understand his aecount, that the lens has a somewhat similar structure to the erystalline cone of Serolis, or, in fact, to the crystalline cone of Isopod crustacea, us far as it is known. From Clarke's deseription I gather that the lens of Phacops is unequally biconrex, the curvalure being the greatest on the proximal surface; and that the lens was hollow, probably filled with some viscid humor. In the absence of a more complete knowledge on the nature of a corneal covering to the eye in the 'Trilobite it is premature to carry out the homology of the "crystalline cone" of Serolis and of the Isopods in general to the "lens" of a Trilobite, althongh there appears to exist a certain resemblance between the two. It is perhaps worthy of mention, in this connectiun, that there is nothing whatever in the lens-cone of Limulus at any period of its development which shows any resemblance to the lens of a Trilobite as male out by Clarke. The lens-cone of Limulus is the solid, conicul projection of the chitinouscuticle of the body, filting into the open depression of the skin, and in no periorl of the life history of the animal is it sepurated from the vutermosl cuticle of the body. (Compare Grenacher, Lankester and Bourne, and Part 111 of the present puper on the eompound eye of Limulus.)

' loc. cit. p. 183.

${ }^{2}$ Untersuchungen uber das Sehorgan der Arthropaden, 1879. 

retiunla, then, anrees with the eorneagen and vitrella which lie uhove, in its eapraeity to secete chitin on a part of its surfice. Thus the three strat $a$ of eells, $a, b$, and $c$, agree fumlimentally with one another in their eaparities to secreto chitimus structures, and these are rispeetively known as the cornea (1), the crystulline ene (2), and the rhathmere (3).

Hence, aside from the general homology which exists between the cells in the optic area, all being derived from a common sonree, the ectolerm, there exists a sperial homology betwen the cells in the three strata which constitute the important parts of the ommaticlimm, all being characterized by the capaeity for secreting chitin from a part of their surface.

In this respect these ommatidial cells are essentially like the general ectodermal eells which secrete the chitinous corering of the body from their distal extremities.

In earrying this analysis further we find that the onter surface of the corneagen is homologous with the axial surtace of the vitrella, and that of the retinula and the three chitinous structures, cornea, erystalline cone and rhablomere, are hounologous with each other.

If this interpretation be established by the further discussion of the ommatidia of other forms, it follows that the crystalline cone and rhabdomere are really homologons with the chitinous in restment of the body, and the narrow axial space of the ommatidium represented by the line $x$ must therefore have the same significance as the space outside of the body. Morphologieally speaking, the erystalline cone and rhabdomere are just as much a part of external surface as the cornea itselt. I'iagramatically, the three strata of the ommatidium may be represented as in Fig. 2, Pl. XXIX.

Aecording to this view, the ommatidiun of Serulis may be recarded as an open pit of the ectolem, the walls and marrin of which are corvered by the prodnct of their own secretion, the ehitin. The chitin in the walls and matrin of the pit beeomes continuous with the general ehitinous covering of the boty, as the rows of the onmatidial cells themselves becone continuons with the general ectorlerm.

At the bottom of the ommatidial pit there exists a pair of colorless "hyaline cells" (Beddard), with their "pper processe's 

inserted into the axial spare hetween the finr rhablomere. Each cell has n peculiar refractive nuelens. It lacks any annection with the optic nerve fibre, and is suspended from the bottom of the pit at a considerable distance above the basement membrane. Thu "liyaliue eell" is a moditied ectodermic cell, and is homolurous with the rest of the erlls which "nter into the furmation of the ommatidimu. The eell, lowever, does not develop pignent granules in itself, nor establish any connection with the central nervous system as does the retinnla cell, nor does it secrete chitin on a part of its surface as do the rest of the ommatidial cells we have consilered already. Is to the function of this cell I an not able to say anything definitely. It eannot be sensory, having mo connection with the nerve centre. When we see, lowerer, that in some species of Serolis the lower ends of the four rhabdomeres are deeply imbelded in the substance of the "hyaline cell," or, in other words, that the rhabdomeres are firmly held together by the substanee of the "hyaline eell" at the point where they meet, it beeomes probable that the cell in question may serve the purpose of a mechanieal support, adding firmness to the whole strueture. To this point I will recur later on.

In addition to the eells which form the essential part of the ommatidium there exists a number of pigmenterl eells, ( $\mathrm{g} g . \mathrm{c}$. Fig. $1 \alpha, \mathrm{Pl}$, XXIX). The pigment eells are greatly developed aromnd the vitrellac and closely in rest the dioptric portion of the ommatidinm from ontside. These pignented cells also are modified ectoderm cells which lie between the adjacent ommatidial pits.

The morphological unit of the componnd eye of Serol's may then be described as consisting of a gromp of ectodermic cells lying ontside of the basement membrane, and so arranged as to form the walls of an open tubular depression. This gromp of rells nndergoes speeial differentiations at diflerent levels of the pit. The uppermost group, consisting of two flattened cells, eonstitutes the corneag'n, which secretes the cornea externally; the seeond group of cells, eonsisting of two large cells, the vitrellac, secretes chitin towards the lumen of the tube, thus forming the crystalline cone; the thirl group of erlls, the retiunlae, consisting of four cells, secretes the rhabdomercs. The retinulae 

are the only eells which are connected with the nerve ecentre. In addition to the three clements above numed, the fourth element, in the form of two "hyaline cells," exists, plugering, as it were, from the inside the imperticet hottum of the depression. A number of pigment vells enveloping more or less completely the above mentioned gromp of cells from the outside constitutes the fifth element of the ommatidium.

A glanee at the diagram (Fig. 1h, P'l. XXIX) will make this point elear. The diagram is supposed to be the plan of the constructive elements of the ommatidinm of sirolis as they would appear when seen from the exterior, in the direction of the arrow, Fig. 1a, Pl. XXIX, if they actually formed an open pit like that shown in Fig. 2.

The innermost body which appears in the depression is the pair of "hyaline cells," $(d)$; next above and therefore in the onter eircle to $(l)$ are the rctinulae (c), the rhabdomeres being represented by the yellow edges. Above the retinulae will come the two extremely enlarged cells, the vitrellae (b), whose chitinsecreting surtace is marked by the yellow color. Next above (b) comes a pair of corneagen cells $(a)$, whose chitin-secreting surface is also represented by the yellow color as in the cells forming the two inner series. The ontermost of all is a pair of extremely flattened, pigmented cells, ensheathing completely the dioptrie portion of the ommatidium.

The diagran is not nulike the one used in illustrating the arrangement of the different parts of a flower. This does not seem surprising when we remember that the nature of the prohlem in both cases is identical. Just as sepals, petals, stamens and pistils of a flower are considered as the morlified leaves elustered round an extremely short stem or axis in whorls or in spirals, so the corneagen, vitrellae, retinulae, etc., are the modified ectoderm eells arranged at diflierent heights on the onmatidial axis. There is, however, this difference between them, that while in a flower the parts concerned in the formation of the organ are themselves aggrentions of many cells, those in the Arthropol ommatilium are highly differentiated individnal cells; and while in the case of the flower it is the elnstering of diflerent parts around an extremely shortened projecting axis, in the ommatidinm of the Arthropod it is the distribution of parts ulong un elongated and sunken one. 

Althongh the sulpject will be much more intelligible after other types have been deseribed, it will not be altogether ont of place here to mention brietly my view of the steps through which the eharacteristic arrangement of parts in an ommaticlium like that of sirolis might luve heen bronght about. Suppose a eirenlar area of the skin to be divided into five zones, on. lying within the other. Mark the innermost cirele as (1), and the next zone as (2), and the middle as (3), the fourth as ( $t$ ) and the outermost as (5). Suppose, further, this eircular area of the flat ectodermal surface of the body to sink down as a conical pit with its open base turned towards the exterior. The eell or cells lying in the innermost circle (1) in the midlle of the area will sink deepest, while the outermost circle (5) will retain its original level. The eells lying in the innermost circle (1) are the "hyaline cells"; those lying within the second zone (2) are the retinulae; those lying in (3) are the vitrellae; those within (t) are the corneagen, and those within (5) are the group of pigmented eells which surround the dioptrie portion of the ommatidium.

All that is necessary to eonvert this diagram into the ommatidium of Serolis is to reduce the lumen of the pit mutil it finally disappears and the cells facing the lumen of the tube come into eontact with each other, or else remain separated by the ehitinous structure; a faint line like that shown by $x$ in Figs. 1, 3 and 4 being all that remains of the axial cavity, like that shown in Fig. 2.

The componnd eye of Serolis is in this view nothing but a collection of these depressions in the skin, which by virtue of their aggregation attain the morphological and physiological valne of an organ.

\section{b. Talorchestia.}

(Figs, 3, 3a, Pl. XxIX.)

$A$ glance at the figures will at once show the fundumental similarity of the ommatilimm of this Amplipod and that of Serolis. Fig. 3, PI. XXIX, shows a single ommatidinm of Talorchestiu. The ontermost covering $e$ is the corneal facet. The two rells which lie beneath it are the cormeagen $(c, y)$. The:e cells are not so conspienous in the adult as in the young 
animals; nevertheless, with cure oue ean easily make them ont. Beneath the eorneayen comes the stratum eonsisting of two rells, the vitrellite, which secrete an enormous (nnciform, ehitinous structure, the erystalline cone (e.c) with its more pointed end turned inward. The erystalline eone eonsists of halves, each corresponding to a single vitrella eell which secretes it on its median, axial surfuce. The line $x$, as in serolis, shows the morphological lumen of the ommatidial eavity.

Next below this stratum comes the group of fonr eells, the retinulae $\left(P_{i} t\right)$. The ehitinous edges of the retinulae meet in the median axis and form the rhablom $\left(I^{2} b\right)$. Transverse striations, rather broad and coarse in their nature, are seen throngh the transparent cuticle, the rhabdomere. At the lower part of a retinula cell, near the basement membrane, is situated its nueleus $(n)$; it may be found below the membrane.

The retinula cell undergoes a curions modifieation at the upper end. Each of the retinnla cells sends out a flattened process which is highly pigmented and which completely ensheaths the dioptric portion of the ommatidium from the ontside. In faet, the place of pigment cells $(p g . c)$ in Serolis is taken by the modified upper expansion of the retinula cells. Ontside of this pigmented sheath there exists a number of non-pigmented, elongated ectodermal cells $(p . c)$ which pack the interspaces between the arljacent ommatidia.

If we plot ont the whole structure into a diagram, in the same way as we did the ommatidia of Serolis, it will assume the appearance slown in Fig. $3 a$, Pl. XXIX. The innermost cells, the "hyaline cells" of Srolis, are not represented; the cells in the second cirele are greatly developed $(R t)$, meeting one another with their chitin-secreting edgee, the rhabdomeres, while the upper extrenity of each retinula cell envelops the erystalline cone from the ontside, thus physiologically taking the place of pigment cells, $(p g . c)$ or 5 in Serolis, Fig. 1b, Pl. XXIX.

In the third eircle the two vitrellae are found with their chitinsecreting surface marked ycllow. The cells in the fourth eircle eonstitnte the corneagen $(c, g)$. The fifth eircle of cells is represented by the packing cells $(p, c)$. 



\section{c. Cantsarus.}

(Fig. 4, Pl. XXIX; Fig. 35, Pl. XXxi; Figs. 71, 79. Pl. XXXv.)

In Fig. t, Pl. XXIX, three ommatidia of C'amberes are represented,,$b$ and $c$. The ommatidimn may be deseribed as in the two preceding cases, as consisting of three stratia of eells, each stratum characterized by the special chitinums product which it secretes. The ontermost stratmu of eells, the eorneagen $(c \cdot g)^{1}$ secretes a slightly bieonvex corneal facet $(c)$.

Next below the eorneagen comes the stratum of vitrellac, consisting of four cells, each with an extremely elongated internal proeess. The median surface of the vitrella which corresponds to the ehiting secreting surface of the vitrella in Sirolis and Talorchistia sceretes a perfertly transparent, homogeneous sulstance, rather refractive in its nature, forming the erystalline cone (a.c). I cannot say anything of the chemical nature of this substance in its relation to the ehitin. The cells which secrete this substance in the crayfish are morphologically identical with the vitrellate in Serolis and Tralorchestia which seerete ehitin, and the use this body subserves in the ommatidim of the crayfish is identical with that of the chitinous body, the erystalline cone, in the two Arthropods we have already examined. There can be no question of the homology of this body to the erystalline eome of other Arthropods. I have therefore represented this body in the vellow eolor as in sirolis and Talorchestir. The ontline of the vitrella ecll in the figure has been made diagramatic to a eertain extent.

Next below the vitrellae come the retinnlae, the whole being aggregated into a spindle-shaped bundle. ${ }^{2}$ On the distal end of

${ }^{1}$ Reichenbach (Studien zur Entwiclungsgeschichte des Flusslirebses, p. 93) speaks of these cells as "Semper'sehen Zellen." In exumining his fgure (Fig. 225, Taf. XIV) we find what he regards as "semper'scells," are those with "Semper'schen Kerne" ( $\therefore$ K. K.) The term "Semper's nueleus" as originally used by Claparide and adopted by others does not mean the nueleus of the eorneagen, as Reichenbach uses it, but means that of the vitrella. In faet the existence of corneagen has been ignored by several earlier writers. It was Patten who emphasized its importance.

"This spindle stratum floes not come from any part of the "augenfulte" of Reiehenbach, but arises in the region where he loeates the eetodermal and mesodermal pigment cells, loc. cit. Fig. 225 , Tuf. XIV. 
$-$

Johus Ţopkins थuisersitn.

Ballimore,

15

Referred by the

saard of Tenciersity

Studies to Prafeosors

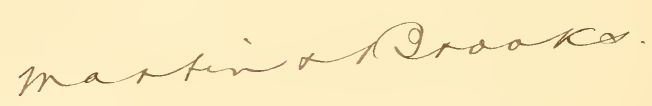


the rhaludom the proximal euds of the vitrellae apparently teruinate.'

When the spindle is marerated amd each of its sompousnt elements is examined individually, it is fomm that mel retiunla develops on its median surface a thiek chitinous border which shuw: a wary, corrugated appenranee. This ehitinous border attains its greatest thickness in the mirlst of the retinula cell (Fin. 35. Pl. XX..I). When the chitin-secreting edges of a number of these relinnla cells meet they form a spindle-slaped bumlle, the thickest part of the rhabdomere corresponding to the mest bulging part of the spindle. The lower extremities of the retimula cells send ont nerve processes, each of which forms an optic nerve fibre, $(\theta)$. n, Figr.t, Pl. XXXI). Fine elongrated alls filled with yellow pigment gramules are tonnd between the adjacent retinula bundles $(e p)$, Fig. 4$)$. They are also the morlified ectodermal eells. The pigment cells which oecur aromel the vitrellate form a complete envelope around the dioptric portion of eaeh ommatidium.

Thus even with this eomplicated type of ommatidinm the plan of strueture is fundamentally alike to that of sirolis. The eentral element, the "hyaline eells" of Serolis, is not represented in the erayfish. To this speeial point I shall recur.

If we plot ont the ommatidial elements of the erayfish as we did those of Serolix, exactly a similar kind of diagram will he formed. Thus in the eentre will come the gromp of retimulat,

'Purker found in Homarus (A Preliminary Account of the Development and Mistulugy of the Eyes in the lobster. Proceedings of the American Aeademy, Vol. XXIV, pp. 24-25, 1888 that the lower extrumities of vitrellae run over the spindle, and that euch terminates on the retinal side of the basement membrane. It is probable that the same is true in Cambarts. This fact is perfectly intelligible according to the view which is maintained in the present paper, for the eells found in the higher level of a given ommatidium are morphologically sirnated in the outside of those found in the lower. Patten's account (Eyes of Molluass and Arthropods, Mittheilungen aus der Zoologisehen Station zu Neapel, Bd. V1, Heft 4,1 kist) that the rhalulom is the continuation of the retinophorae (vilrellae) is not true. I macerated the "spindle" of Penaeus, upm which Patten bases his observations, and found that it is comprosed of a number of pigmented retinula cells, eneh with its chitinnus border us in Cambarus (Fig. 3.5, Pl. XXXI or in Ilomarus Fig. 34, Pl. XXXI). Grenuher is riyht in regarding the rhabdon as the secretion product of the retinula cells. 

consisting of seren cells; then come in the ontside four vitrellae arranged in a square; then two corneagen cells; and ontermost of all, four pigmented eells which completely envelop the dioptrie part of the ommatidium.

\section{d. Ilomarus.}

(Fig. 34, Pl. XXxi.)

The compound eye of Homams has quite recently been stulierl by Parker. ${ }^{1}$ I do not find any facts in Parker's paper which contradiet the view maintained in the preceding pases in regard to the nature of the ommatidium. The threefold diflerentiation of the ectodermal eells in the walls of the ommatidium is just as evident here as in the forms already eonsidered. The problematical body, the spindle (Grenacher's rhabdom), like the corresponding structure in Cumburus, resolves itself into a number of individual retinula eells with thick, serrated, chitinous secretions as in the case of Cambarus and Penaers.

In Fig. 34, Pl. XXXI, fonr retinnla cells are partly isolated from one another. The lower end of each retimula cell is prolonged into an optic nerve fibre, while the upper end is devoid of any pigment granules. A large translueent nueleus exists near the distal extremity of the retinula. The distal end of each eell is prolonged into a short, elearly defined, tapering process. The development of the chitinons serrature is greatest in the middle of the ehitin-secreting border of the retinula; when, therefore, the whole is brought together into a bundle, the general ontline of such a structure is spindle-shaped.

\section{e. Callinectes.}

(Figs. 5, 5a, Pl. XXIX; Fig. 37, Pl. XXXI ; Fig. 72, Pl. XXXV.)

Callineetes presents the same interesting modification which we saw in Talorchestia. We find the eorneagen cells and the vitrellae in two snecessive strata, but no special pigment eells embracing this dioptrie mechanism exist. The packing eells which we saw in the intervening spaces of the ommatidia in Talorchextiu are not found in Cullinectes.

'G. II. Parker: A Preliminary Account of the Development and Mistology of the Eyes in the Lobster. Proc. Amer. Aesd. Vol. XXIV, 1888. 

The third stratum of eells, the retimular, are extremely elongated, each retinula with a elear, strnight, finely strinted rhablomere. A somewhat diagramatic representntion of the inclividual retimnla eoll with its ehitinons border is griven in Fig. 37, Pl. XXXI. In Fig. 5a, Pl. XXIX, the upjer portions of the two retinula cells are shown; the rhaldonere just leneath the crystalline eone shows a slight enlargenent. The size of the retinula eell at the distal extrenity undergoes an enlargenent. The enlarged extremities of the retinulae form a pigmented eollar around the inner end of the crystalline eone. If the upward extension of this part of the retinula cells be carried still further, a conclition which prevails in a retinula like that of Tulurthestic will be fonnd. In the freshly teased preparation, one ur more retractive globules, ranging from yellow to reddish brown in eolor, are found in the thickened portion of the retinula. The general shape of the ommatidium as determined by the shape of the eorneal facet is hexagonal.

For the general disenssion of the sulject I do not find it necessary to go into further details of comprarison, nor to enumerate more examples from diflerent Arthropors. In the forms I lave studied in this eonnection, representing near thirty Arthropod genera, I found nothing which invalidated the general interpretation of the ommatidial structure of the Arthropod as explained in the preceding pages, and the eomponnt eye of the Arthropod, whether it be sessile or stalked, must be held to represent morphologically a group of ectodermal pits or a bundle of ectodermal tubnles.

\section{III.-The (ompound (Lateral) Eye of Limeics.}

The question which next sugrgests itself is this: Adopting for a moment the view that the ommaticlium of the eompound eye is morphologieally an ectodermic pit, is there any adult arthropod whose eye permanently remains in this condition?

I find sueh an ommatidimu in the componnd ere of Limulus.

On this account I will deseribe the eyes of Limulus somewhat in detail. ${ }^{1}$ In the eneceeding section of the paper I will point

${ }^{1}$ An outline of this portion of the paper will be found in the Mareh number of the liniversity Circutar, 1889, Johns Hopkins University, under the title The Structure and Development of the Eyes of the Limulus. 

ont how an onmatidinm like that of Limulus may be eonverted into one of a more complex type.

$$
\text { a. Gemeral sketch of the Componumel Eige. }
$$

The eompound eye of Limulus is placed in the dorso-lateral nngle of the prosonatic shiek. In the fully grown animal the outline of the eye is bean-slaped, with it's longer axis parallel to the longitndinal axis of the body. This bean-shaped area is slinhtly protuberant from the surrounding level; the chitinons covering of the body is thinner, softer, and more translueent in the region of the eye than on the rest of the dorsal surtice. Through the translucent chitin we see a large number of eircular epots, all of a uniform size. On further examination we find that each spot eorresponds to a conical projection of the chitin, which fits into a eavity in the skin. This conical thickening of the ehitin constitutes the lens or lens-cone, and the gronp of cells forming the walls and bottom of the open cavity constitute the essential part of the ommatilium.

The cells whieh form the walls of the pit are elongated and highly pigmented, forming the perineural cells (p.n, Fig. 6, Pl. XXIX): those eells which form the bottom of the pit undergo extreme enlargement compared with the perineural celle, and elongate along the longitndinal axis of the pit. They are grouped in a characteristic manner, reminding one of the arrangement of cells in the taste-bulb of a rertebrate. This bulb-like group of cells is the essential part of the retina. In my preliminary aceount of the subject ${ }^{1}$ I ealled this group of cells an ommatidinn. Properly speaking, the term ommatidium includes the whole group of cells forming the walls and bottom of the pit, togrether with the lens-cone and the thick ehitinous covering corresponding to the area oceupied by a single pit. In this latter sense the term ommatidium will be used in the present paper, and the bulb-like grvup of "ells at the bottom of the pit will be designaterl as the sinsory purt of the ommatidivm.

In the sensory part of the ommatidium, whiclı consists of two portions, a central $a$ and a peripheral $b$, the arrangencent of the cells is quite regular.

$$
\text { 'loc. cit. p. } 70 .
$$


The central purt always consists of a single ganglion ecti ( $r$, Fig. 6, Pl. XXIX), and the peripheral of the rod-bearing pigmented cells (lit, Fig. 6) which surromel the formor in the eentre. As to the minute structure of these elements I shitl speak later on. The cells composing the enensury portion of the onmatidium send out from their proximal ends nervons processes, which, forming a bundle, are seen to emanate from the basal end of the ommutidiun. The number of nerve fibres at the beginning of the bundle and that of the eells composing the sensory bulb of the ommatidium always correspond. These bundles, however, soon break up as they penetrate deeper, and beeome mixed up with the fibres from the neigliboring bundles, forming a complex plexus underneath the ommatidial area. Scattered in the plexus are found a number of thickenings, which, in goluehloride preparations, appear as darkly stained masses of protoplasin oceurring at the nodes of junction of the several intererossing fibres (Figs. 44 and 45, Pl. XXXIl). In the fresh state these enlargements contain a variable amount of yellow granules imbedded in the mass of the protoplasm. In the figures above referred to, mere outlines of such thickenings are given.

After the nerve fibres have formed the plexus they again come out in bundles, and piercing throngh the perforations in the basket-like ehitinous support which underlies the ommatidial region, travel forward, slightly inward, then downward and backward until they terminate in the optic ganglion in the brain.

\section{b. The structure of the (Immatilium.}

In the general sketely of the compound eye of Limulus above given, the structure of its morphologieal unit, the ommatidium, has been brietly described. It eonsists of two parts, (1) the sensory and (2) the dioptric part, which is also partly proteetive.

The sensory part consists of two factors, (u) the eentral element or the ganglion eell ( $(\dot{r}, \mathrm{Fig} .6, \mathrm{Pl}$. XXIX), and $(b)$ the peripheral elements or the retinulae (lit, Fig. 6). These two kinds of eells are the only ones in which nerve fibres terminate.

'The retinula cells group themselves in the shape of' a bulb, or something as the several segments do in an orange, caeh segment corresponding to a single rod-bearing eell or retinula ( $\mathrm{Fig.} \mathrm{10,}$ 

It, Pl. XXX). Along the axial side of the retiunda cell there exists a definite longitudinal truct which is free from the pignent granules. ()n the outside of this colorless region there exists a thin layer of chitin. This chitinons covering on the outside of the retinnla constitutes the rod or the rhabdomere $\left(h^{3}\right)$, Fig. 10 , Pl. XXX). When the non-pigmented portion of the retimula eell is examined with a ligh power, we find the whole structure to be transversely striated. This striated appearince seems to be prorluced by the existence of an enormous number of transverse fibrils lying in the inside of the ehitinons enticle. That these striae are due to the existence of independent fibrils is further shown by the fact that by eareful focusing up and down of the microscope some striac can be directly traced ont beyond the limit of the chitinons ensering, in the form of independent fibrils (Tr.fl, Fig. 10, Pl. XXX).

When we make a transverse seetion of the retinulae, each cell will present a wedge-shaped outline, with its pointed end turued toward the axis of the ommaticlium; the non-pigmented part of the eell in its relation to the entienlar secretion on the outside will be seen from the diagram (Fig. $6 a, b, R l$, Pl. XXIX).

The number of retinula cells entering into a single ommatidimn is quite variable. Thus, Grenacher ${ }^{1}$ counts fifteen; Lankester and Bourne ${ }^{2}$ eount ten; I have found some with eleven, other with nine; in one ommatidium I counted as many as nineteen.

I am not able to say under what ronditions this numerieal variation takes place. Whatever significance there may exist in this numerical variation, it does not alter in the least, as in the case of diflerent elements in other ommatidia we have alrealy considered, the grneral idea that the ommatidiun of the Arthroporl is morphologically a depression in the skin.

Each ommatidimu contains a single ganglion cell. Only in one case did I see two ganglion celts in a single ommatidinm. The sanglion cell is situated morpholorieally in the centre of the sensory part of the ammatilimm. The rotinula cells complately cnvelop, this ganglion cell from the outside, in a similar way as the rods eneirele the cone in the eentre in the retinae of some vertebrates.

'loc. cit. Fig. 125, Tat. XI. $\quad$ 'loc. cit. Fig. 10, Pl. XI. 

The main body of the granglion eell where the nueleus is situated is found in the lower part of the ommatidium, ocenpying in most eases an eerentric position. Figs. 13, 14 and 15, P1. XXX, show three granglion cells emmpletely isulated from the rest of the retinal cells. In Fig. 10, Il. XXX, the relation of the ganglion eell to the retiunla cell is well shown.

The gatuglion cell is distinguished by constant and well marked features fiom the rest of the ommatidial cells. The cell is bi-polar, the one process going upward and outward through the axial channel of the ommatidium (the axial canal of the rhabdom), and the other going downward and inward to the subommatidial plexus and thence to the brain. For the sake of eonvenience the former will be designated as the axial process (Ax. p, Figs. 13, 14, ete.), and the latter as the optie nerve proeess (Op, n, Figs. 13, 14, etc.) of the gangrlion eell.

The axial process gradually tapers to a narrow point. The process eonsists of a bundle of extremely fine fibrils, which are distinutly seen as a series of longitudinal striae. For some mechanical eanses, the distal process was seen split into three main branches in one specimen ( $\mathrm{Fig} .15, \mathrm{Pl}$. XXX); in another specimen (Fig. 10), the topmost end of the axial process was seen eompletely maeerated into a number of component fibrils, the whole slowing a brush-like appearance.

The large, translueent, splrerieal nueleus ( $X$, Figs. 10, 13, 14, 15, Pl. XXX), with its nucleolus, is fouml in the substance of the eell body proper. The position of the nuclens is very often ecentric, as in Fig. 14. The nucleolus is surrounded by coneentrie markings in all eases. Between the nucleus and the proximal process there is always a larger or sualler patch of pigment granules ( $\mathrm{Pg} \cdot \mathrm{P}$, Figs. 10, 13, ete.). The color of the granules ranges from light yellow to dark brown or even to jet black. The yellow-eolored pigment is diflused more or liss widely through the body proper of the ganglion cell. Even in the same pateh of pigment in the eell there are different gradations in the color. From the nature of the drawing nsed in the present paper I eannot show these gradations. I'igment. patches may exist in other parts of the cell, but they never form so constant a characteristic as the group between the proximal process and the nucleus. 

The third element which figures prominutly uround the sensory cells of the ommatilium is the eipithelial eell. The cell muy either be pigmented or non-pigmented. In Fig. 11, Pl. X.X, n gromp of four retinula cells is shown partly isolated from one another. Within the interspaces between the adjasent retiunla cells will be found a number of pigmented "pithelial eells, extremely elongated, many of them extending the whole length of the retinula cell. In Fig. 12, P. XXX, a number of highly attenuated epithelial cells $(E p)$ is slown closely clinging to the onter surface of the retinula cell. In Figs. 10, 13, 14 and 17 highly attennated epithelial cells $\left(E_{p}\right)$, both of the pigmented and the non-pigmented kind, are shown, as they oecur either arumd the ganglion cell or around the retinula cell.

In no ease are these epithelial cells found to establish any organie connection with any part of the sensory cells or of their processes. These attenuated epithelial cells do not differ in any essential way from the ordinary ectodermal cells which are found in the walls of the ommatidium or in the seneral eetolerm.

The epithelial cells as they further depart from the periphery of the group of sensory cells, beeme stouter and thicker. One end of each epithelial cell is usnally devoid of pigment granules; this non pigmented and of the cell secretes the ehitin which forms the lens cone. We lave already seen that the portion which secretes the chitinons covering, the rlabdomere, of the retinula cell is deroid of pigment granules. In this respret the epithelial cells which form the wall of the pit and the nenroepithelial eells which form the bottom of the pit closely arree with each other.

A glance at the series of figures (Figs, 17-33, Pl. XXXI) will show the degrees of modification undersone by the epithelial cells teasid ont trom the different parts of the ommatidium. Those cells (Figs. 17 and 18) which lie at the bottom of the pit undergo the greatest modification. Fig. 17 is the rentral ganglion cell of the ommatidium, with a fiow slender epithelial cells around it. Fig. 18 is the retinula cell with a few pigmented epithelial cells elinging to its sile. Both differ from the rest of the epithelial cells in their possession of nerve processes. In some epithelial cells, as in Figs. $2 \checkmark$ and 25 , Pl. XXXI, the degree of attenuation is so very great that the protoplasmic character of 

the cell body is hardly recognizable. The cell botly is represented hy an extremely slender, bristle-like tilament, with no pigment gramules in the insirle. In otluers this hyulinc eell borly is dirided into a number of branches, as shown in Figs. 21 and 24 , Pl. XXXI. In other ones, one-half of the cell body is rerluced to a hyaline filament, while the other half retains a protoplasmie natnre, with a greater or less amount of pigment granules as in Figs, 19, 20 and 24, Pl. XXXI; while in still others the protoplasmic substanee is mostly gathered around the molei and the two extremities redueed to hyaline struetures with no pirment granules in them, as in Firs. 22, 24, 27, 29 and 30, Pl. XXXI.

The contents of the ommatilimn of Limulus may be pnt, then, under two categories: (1) the epithelial cells; (2) the prodncts of secretion of these eells. The first may be classified into two principal divisions: (a) the nenro-epithelium, (b) the ordinary epithelinm. The nenro-ejithelium is of two kinds, the cen/mil, ganglion rell and the peripheral, retimula cells. The ordinary epithelinm shows all varietirs of modifieation, and exists either in the interspaces of the neuro-epithelimm or around it. The products of secretion may also be put under two heads: $(a)$ the ehitin secreted by the nemro-epithelimn (the retinnla cells) forming the rhabdom; (b) the chitin seereted by the ordinary epithelium forming the lens cone, and the entire chitinons strueture lying over the pit.

The basement membrane ( $B . M$, Fig. $($, Pl. XXIX) underlies the whole ommatidium, separating it eompletely from the underlying mesodermic tissue (.1\%, Fig. 6, Pl. XXIX). It the bottom of the ommatidinm the basement membrane follows the course of nerve fibres issuing from the bases of the neuroepithelial ("ells, anrl thus forms a complete sac to the bundle of nerve filres. When the bundle breaks up in the plexus the basement membrane sheath of the optic nerve fibres hecomes indistinct.

A stuly of transverse sections of the ommatidium at diflerent heiglits will show the relative positions of the component elements a little more clearly. In Fig. $6 a, 1$ 'l. XXIX, transverse seetions of the ommatidium ent at four diflerent levels are shown, and will be intelligible if one compares them with Fig. 6, PI. XXIX.

In (i ) Fig. 6u, the plane of section passes near the opening of the pit. In the centre is found a portion of the lens $(L)$, and 

surrounding it a circulur row of colnumar pigmented epithelium. The lens is secreted by the surrounding (w)hmunar cells. Around the whole ommatidimm there exists a rather thick, well defined basement membrane ( S. . W) which separates the omuatidium from the mesodermic tissues $(M / s)$.

In (b) Fig. tia, a section at about the level of the letters lit, in Fig. $t$, passing throngl the sensory portion is shown. The main contents of the ommatidial eapsule $(B, I f)$ are the retinula cells $\left(I^{\prime} t\right)$. The axial moiety of each retinula eell is free from the pisment granules, and a thin cutienlar eovering is secreted around this portion of the eell. This cutieular eovering constitutes the rlabiomere $(l i h)$. Sections of a number of pigmented eells are seen lying between the retinulae and the basement membrane; these are sections of the prinenral epithelial cells.

In (c), Fig. $6 a$, a seetion passing throngl the body of the ganglion cell $(G)$ is shown; the ganglion eell is surrounded by a circle of retinula eells, which are now gralually tapering, each into a slender nerve proecss. The ganglion cell takes a more eecentric position in (d) than in $(c)$. The retinula cells ( lit) in $(c)$ and $(d)$ are represented by the eirele of nerve fibres surrounding the ganglion cell $\left(f_{r}^{*}\right)$.

In (e), Fig. $6 u$, the seetion passes throngh the bottom of the ommatidium; all of the sensory cells are reduced into nerve fibres whieh proceed one from the bottom of each eell. The bascment membrane (l,.$M$ ) is still distinetly seen, forming the sheath of the nerve bundle. The interspaces of the adjacent ommatidia are oceupied by the mesodermic conneetive tissue.

If we plot ont the arrangement of the eomponent elements in the ommatidiom of Limulus, the appearance shown in Fig. 7 will be presented. The epithelial cells $\left(E^{\prime}\right)$ forming the walls of the pit are drawn with their chitin-secreting surfaces turned towards the axis of the ommatidium, which is morpholegically the exterior surface of the body.

\section{c. The Development of the Compound Eye.}

The first ruliments of the compound eye appear extremely early in the embryonie stage as a pair of eetorlermal thickenings alove the levol of the "dorsal organ." In Fig. 59, Pl. XXXII, * shows the place where the compound eye makes its 

appearance. In this stage the "dorsal oryan" $(D, O)$ is alrearly very prominent. The eye itselt' does not slow its charaturistic invagination, but is represented by a slightly thickened patrh of the ectoderm; exespt in the microseppie examination of the sections it is hardly recognizable. The section Figr. 42, I'l. XXXII, slows an embryo considerably more advanced than Fig. 39. The plane of section passes obliquely forwarl from behind, and ents both the eye $(E)$ and the "dorsal organ" (D). (1). The most noticeable feature in this stage of the development of the eye is the existence of the lateral invaginations at the edges of the ocnlar area. The section shows three portions, the dorsal fold $\left(d, f^{\prime}\right)$ and ventral fold $\left(v, f^{\prime}\right)$, with the median portion $\left(E^{\prime}\right)$ between them. The groove along which the ectoderm invaginates is V-shaped, with the pointed end turnerl towards the posterior end of the body. As the invagination beeomes deeper, the pointed end of the $V$ becomes prolonged into a tube, which works its way beneath the general surface of the eetodern. This tubular invagination of the posterior part of the eye will be called the median fold of involution $\left(m . f^{\prime}\right)$ in our subsequent deseriptions.

The whole outline of the invaginated area may be represented by $Y$, the area intereepted by the two divergent branches of the $Y$ being the onmatidial portion, while the posterior stem of the $Y$ is the continuation of the lateral depressions, the median fold, extending backward and downward beneath the surface of the general ectorlerm.

The opening of the tube is at the junetion of the two divergent branches of the $Y$ with the posterior median stem.

Figs. 47-56, Pl. XXXIII, represent a series of transverse sections of the compound eye in the stage represented by Fig. 42, Pl. XXX11. Fig. 47 is the section passing through the anterior end of the oenlar area. The ectodermic cells are considerably thicker than the general ectoderm in this region. The section which comes immediately behind this is not griven in the plate. Fig. 48 shows essential characters of the section which immediately follows the section Fig. 47. At two portions of the thickened cetoderm, $d . f^{\prime}$ and $v . f$, the eclls arrange themselves in radial fashion, aceompanied by a characteristic ehange in each nuclens, which becomes coarsely granulnr and peculiarly translucent. 
In examining the next section, Fig. 49, the radial arrangement of eells in the above section is shown to be the berinning of invagination. In Fig. 4: the lateral invaginations $d . f$ and r. $f$ have each a well developed lumen. In the median side the walls of the invarinations become continuons with the group of finely divided cells, eneh with darkly stained nuclens. This group of cells give rise to ommatidia. The outer wall of each invagination becomes continuous with the columnal epithelial covering of the borly.

Figs. 50 and 51 show essentially the same thing. The ommatidial area $(1 / m)$ in Fig. 51 beeomes wider than in any of the preveding sections.

Just at the point where the maximum width of the ommatidial area is rearhed ( $\mathrm{Fig} .51$ ), it again begins to become narrow, for in the section (Fig. 52 ) which eomes immediately behind that shown in (Fig. 51), the ommatidial area is narrower compared with that shown in Fig. 51, and the two lateral folds of invaginations approatch each other, resulting in a fusion in the median line in Fig. 53. In Fig. 5t the fiused lateral folds, resulting in the formation of the median fold $(m . f)$, begins to work its way beneath the level of the skin. In Fig. 55 a few cells $\left(m . f^{\prime}\right)$, forming the posterior extremity of the median fold beneath the skin, are found. The section (Fig. 56) passing behind that shown in Fig. 5.5 shows no trace of invagination of any kind.

The anterior end of the eye, then, begins with Fig. 47; two sections behind it a beginning of lateral invaginations becomes discernible; at Fig. 53 the two lateral folds finse, and at the ninth section (Fig. 54 ) they form a median tube $\left(m . f^{\prime}\right)$, and at Fig. 56 the posterior bondary of the ommatidial area terminates.

In Firs. $45 a$ and $46 a$ are shown the longitudinal sections of the eve. The ommatidial cells in the anterior portion of the eye send ont nerve fibres which form the optic nerve (/Ip.n). The basement mimbrane $($ B,,$/$ ) which underlies the ectodermal cells forms a complete sheath to the bundle of optic nerve fibres going to the optic gamplia of the lrain, which are formed by indefendent involutions on the ventral side of the body." The origin

'The optic ganglia arise as ectodermic involutions in the pre-oral region of the animal. Owing to the existence of a great cephalic flexure in Limulus, that side where the optic gunglia as well as the median eye originate has cor the sake of convenience been called the "ventral side." 

of the optic nerve filmen is further shown in Fig. 4:3, Pl. XXX11. The lignre shows an oblique transverse section throngh the ommatidial region of a more advanced mubryo than the one slown in Fig. fise, Pl. XXXIll. The plane of section passes through the ommatidial area and thromgh the bundle of the optie nerves, which run forward. The migration of the eretolermal eells seems to take place from the periphery to the inside of the boly. The basement membrane ( $3 . M$ ) forms a rontinnous sheath around this migratory stream of ectodermal cells.

In Fig. 4", PI. XXXII, is shown an embryo in the so-ealled "trilobite stage." I pair of round protuberant organs (D. (I) in front of the eyes $(E)$ are the "dorsal organs." The eye is distinctly marked in this stage, owing to the formation of pigment granules in the component eells. Except in the general enlargement of the organ and the formation of the pigment granules in the cells, the eye in this stage does not ofler any material diflerence from the eondition seen in the stage which we have already examined (Figs. 47-56). After the first moult of the chitinous covering from the condition represented in Fig. t), Pl. XXXII, it passes into a more adranced condition when the essential Limuloid features characteristie of the adnlt become distinetly discernible. Fig. 41, Pl. XXXII, represents the young Limulus at its first stage in the accunisition of the external Limuloid features. The whole body is translueent; the ehitinous covering of the body is yet extremely thin, and the dendritic ramilications of the "liver" containing the remnant of the food-yolk of varions hues, sometimes green, at other times yellow or pink, shine through the transprent tissues of the hody.

The eompound eye $(E)$ shows an interesting feature in eonnection with the formation of the ommatidial area.

Figs. 5i-64, Pl. XXXlV, show a series of transver-e sections thromgh the compound eye in the stage blown in Fig. $41, \mathrm{Pl}$. XXXII.

Fig. 57 , Pl. XXXIV, represents a section passing throngh the anterior part of the eye. The eetoderm in the ommatidial area is thrown into a number of tiolds. The cells lying in the valley of the foll are destined to give rise to the ommatidium. In the dorsal matrgin of the ommatidial area there exists a thick layer of ectoderm, eonsisting of a number of large cells, each with 

granular protophasm and a large nucleus. At the basal end of each cell there exists an aecmmulation of transparent liqnid substunce. Beneatl ommatidial area a well defined basenu'nt menbrane ( $D .3 /$, which is the continution of the sume menthrane existing under the general ectuderm of the hody, sharply marks out the ommatidial strueture from the nesolernir. tissurs.

In Fig. is, which is taken a few sections behind the precedins, is shown the ommatidial area at its widest part. Four ommatidia formed by the undulating folds of the eetolerm are shown, each depression being arempanied by a eorresponding thickening of the chitin, forming the rudiment of the lens-eone $\left(C^{\prime}\right)$.

On both sides of the ommatidial area we find the lateral invagination of the ectoderm. The eells forming the invaginated folls undergo enormous enlargenent, and in the basal end of earlh cell is shown a large accumulation of transparent fluid. The cells forming the inner walls of the dorsal and ventral folds of invaginations undergo various metamorphoses. Each of them beeomes divided into a number of sinaller eells, each of these segments being parked witl extremely fine pigment grannles. As the eells in the inner walls of the dorsal and ventral folds $\left(d . f, e . f^{\prime}\right)$ become divided up into a number of smaller pigmented segments, they are constantly pushed out towards the surface, where they, gromping themselves into a number of ommatidia, increase the general surfice of the ommatidial area. Thus, the older ommatidia are found in the middle and the younger ommatidia are to be found around the marginal portion of the oenlar area.

In Figr. 59 a section is shown in which the ommatidial area is narrower than the preeding. In Figs. 60 and til this narrowing of the ommatidial portion eontinnes, and in Fig. 62 the dorsal and the ventral folds neet in the median line. In Fig. 63 the median fold becomes completely buried beneath the general ectoderm. In Fig. 6t the seetion passes near the posterior extremity of the median fuld, where the reduction in the size of the tube as well as its increased distance from the level of the general eetuderm is clearly discernible.

In all the fignres above described Py. $c$ means the pigment cells, which in the state of nature are highly pigmenterl, each with a small eecentric nucleus. Each section has been carefinlly 

depigmentel, withont which the process of the formation of the ommatidia and the increase of the ocular area is perfertly unintelligible. Those cells in the figures which have no gramular structure are, in the stute of nature, charged with a large quantity of pirment granules, and those large eells forming the walls of the lateral folds are graunlar and free from pigment granules.

Transverse sections are not fitterl for the stuly of the firmation of the nerve fibres. In this stage, as in the preceling ones, each ommatidium sends ont nerve fibres from its basal end towards the interior of the body. Besides the eells in the hottom of each ommatidial pit, each gigantic cell of the onter walls of the dorsal and ventral folds sends out a nerve process from its basal end, which rnus inward and forward, joins the nerve fibres from the hottom of each ommatidium, forming a large bundle, and goes to the brain.

The invagination of the lateral and posterior margin of the ocular area is usually not permanent. With a growth of the animal and an increase of the surface of the ocular area, the invarinated folds, both on the sides as well as behind the ocular area, become stretehed ont in the alult animals and leave no trace of their existence. Oeeasionally, however, one nueets in the adult with a remnant of the involuted tube in the posterior part of the eye, which exists as a ball of pigment cells buried in the midst of the mesodermic tissur.

The history of the ommatidial cells in the componnd eye of Limulus may then be stated in the tollowing way:

(1). A stage of undiflerentiated ectorlermal eells.

(2). Thickening of these undiflerentiated cells, accompanied with the invagination beneath the surfaee.

(3). Extreme enlargement of the invaginated extoderm, followed by the aequisition of pigment granules and by division.

(4). Pushing ont of the resulting sinall pigmenterl cells towards the surface where they differentiated into two findamental groups: (a) Ordinary epithelial eclls, which secrete the chitinons cnticle over the ocular area, including the lens, or pack the interspaces of the neuro-epithelinm; (b) nenro-epithelium, ensisting of the rud-bearing rutinulace and the central ganglion cells, the two forming the sensory portion of the ommatidium. 


\section{IV.-Puyloone of the Omatrimes.}

I do not pretend to enter into a detailed discussion of this diflicult problem. In ordir, lowever, to give a more intelligent idea of what I have thus far been eonsidering, I will devote the following pages to the reconsideration of facts griven in the preceding pages trom a more empreliensive standpoint.

Baltom ${ }^{1}$ has given a sketeh of the possible evolution of a visual organ. Ile starts with a simple organism in which $r$ spot on the surtace of the body may become spontaneously pigmented and the refore beeme specially sensitive to light. The euticular covering of the body may become thickened at this spot and act as an apparatus for eondensing the light upon the pigmented spot lying beneath it. He further expresses his view elsewhore ${ }^{2}$ that the lens-like dioptric apparatus of the eye, formed either as a thickening of the entiele or as a mass of eells, was at first formed simply to concentrate the light on the sensitive epot; the power to throw an image of external objects on the perceptive part of the eye was acquired gratnally afterward.

The part whieh is played by pigment in the pliysiolosy of rision is considered a most obseure problem. I quote the following, clearly put forward by Foster, ${ }^{3}$ as a physiolosical aspect of the question bearing upon the diseussion at issue: "But in order that light may prorluce ehemical oflects (upon protoplasm), it must be absorbed; it must be spent in doing the chemieal work. Aceordingly, the first step towards the formation of an organ of vision is the differentiation of a portion of protoplasm into a pigment at once capable of absorbing light and sensitive to light-i.e. nndergoing decomposition "pon exposure to light. An organism, a portion of whose protoplasm had thus become differentiatel into such a pigment, would be able to react towards light. The light falling on the organism would be in part alsorbed by the pigment, and the rays thus absorbed would produce a chemical artion and set free chemical

'F. M. Balfour: Adilress to the Department of Anatomy and Physiology, British Assnciation, 1480); Nature, Vol. XX11, p. 417, 1840.

${ }^{2}$ Comparative Embryology, Vol. I1, Chapter XVI, Organs of Vision, p. 470.

31. Fuster: A Test Book of Physiology, 4th Fdition, Book 111, Chap. 11: Sight; 'The Photochemistry of Retina, pp. 515-516. 

substauces which letore were not present. We have only to suppose that the chemieal substanee's are of such a nature as to aet as a stimulus to the protoplasm of other parts of the organism (and we have manifold evidence of the exquisite sensitiveness of protoplasm in feneral to chemical stimuli), in orler to see how rays of light falling on the organism might excite movements in it, or modify movements whieh were being carried on, or might otherwise aflect the organism in whole or in part. Such eonsiderations as the foregoing may be applied to even the eomplex organ of vision of the higher animals. If we suppose that the actual terminations of the optic nerve are surrounded by substances sensitive to light, then it becomes easy to imagine how light, falling on these sensitive sul)stances, should set free ehemical hodies possessed of the property of acting as stimnli to the actual nerve-endings, and thus give rise to visnal inpulses in the optic fibres."

Lubbock: advanees essentially the same idea as Balfour's in his recent work on the sulject, illustrated with sone lurid diagrams. "In the simple forms," he says, "the whole surfaee is more or less sensitive. Suppose, however, some solid and opraque partieles of pigment deprosited in eertain eells of the skin. Their opacity would arrest and absorb the light, thus increising its effect, while their soliclity would enhance the effeet of external stimulus. A further step might be a depression in the skin at this point, which would serve somewhat to proteet these differentiated and more sensitive eells, while the deeper this depression the grenter would be the protection."

That such steps of gradual development of visual organs have actually taken place in some forms is quite probable. In Arthrupork, it seens to me worthy of remark that the ommatidium of the laterul eye of Limulus makes the nearest approach to this primitive condition. It is nothing more and nothing less than a depression in the skin, with the thickened chitinous cuticle fitting in the open eavity and aeting as a lens to eondense the light. The cells which form the Eensory part of the structure are modifird ectodermic cello, and, like the rest of the extotermic cells lying on the surface of the body, secrete the chitinons cuticle on

\footnotetext{
In the Senses, Instinct, and Inlelligence of Animals, Inter. Seie. Series, Vol. LXIX, 1888.
} 
a part of their surfice. Assuming the surfice where the chitiu is secreted to be the "xterior, we may describe the ommatidimn of the lateral eye of limulus as a group of modified ectorlermic cells ngregrited around and beneath the funnel-shaped depression in the skin. A glance at the diagrans (Fig. 6, Pl. XXIX; Figs, (i5 and 66, PI. .XXV) will show this clearly. The sensory cells of the ommatidium eome into direct eontact with the enical lens, which is the thickenel part of the general enticle; or, to express this in the phraseolngy of Lankester and Bourne, the ommatidium in the lateral eye of limulus is "epistatic." The cornea and irystalline eone as such have no scparate existenee in this stage.

Suppose such an onmatidium to beeome duplieated until a considerable number be formed, as we may safely inagine to have been the ease, from the general tendency in the perteetion of a visual organ. What will be the result! The first effeet of such an increase of the number of ommatidia in a given area will be the lengthening of each unit in the direction of the ommatidial axis, and the cells ( $V$, Fig. 67, Pl. XXXV) whieh were situated direetly on the outside of the retinnlae will travel over and above the sensory portion ( $R t$ and $G$, Fig. 67). The distal ends of such cells ( $V$ ) which were thus pushed over will

- meet one another in the median or the "optic axis" of the ommatidium: further, they will continne to seerete ehitin (c. $c$, Fig. $f_{i}$ ) from their original chitin-secreting surfaces which are now median and axial. The elitin thus secreted will have an independent existenee from the cornea, thus forming the rndiment of the crystalline eone, and the cells themselves will form the vitrellae ( $V$, Figs, 67,68 , ete.). Finally, as the deepening still further goes on, the corneal lens $(C)$ and crystalline eone (c.e) will be entirely separated, thus producing a condition somewhat similar to that which obtains in Serolis (Figs. 69 and 70.$)$

From this point onward, the three chitinous struetures, comed, rrystalline come, and rhutulomere, nndergo a diflerent development in diflerent Arthropods. In some the erystalline cone assumes a transparent semi-liquid state, whil the whole eell becomes extremely elongated, forning the erystalline cone of certain crustacea (Fig. 71, Pl. XXXV); it may form a hard 

(chitinous ball as in Serolis (Fig. 70, PI. XXXV); or a cuneiform chitinous structure, as in Talorehestia (Fig. 73, Pl. XXXV); or finally the whole cell may remain as a clear, transparent body, as in several insects, forming Grenacher's "aconous type" of the componuct 'ye.

The forms assumed by the rlabdoneres in diflerent Artliropods are equally diverse. The rhabdomere may exist as a plain cuticular covering over the non-pigmented part of the retinula, as in Limulus or in Serolis (Fig. 10, R'l, PI. XXIX; Fig. 35, l'l, l'l. XXXI, ete.); it may become extremely elongated and narrow as in Musca or in Callinectes (Fig. 5, lib, Pl. XXIX; Fig. 37, lil), Pl. XXXI; Fig. 72, Rb, Pl. XXXV); it may become transversely folded as in Cambarus (Fig. 35, lil, Pl. XXXI; Fig. 4, lib, Pl. XXIX; Fig. 71 , l'b, Pl. XXXV); these transverse folds may become still finer, showing the chitinous serrature along the axial edge of the retinula, as in Penceus and Ilomarus (lïg. 34, lib, Pl. XXXI); or this transverse serrature may becone extremely fine and regular, as in Squilla (Fig. 36, Pl. XXXI).

The eornea undergoes equally diverse modifications according as it is purely protective, or partly protective and partly dioptrie in function. The range of variation is shown by the degrees of curvatures and by the varieties of its thickness. In several of the decapod erustacea which I lave examined, as Penaeus, Cumburus, Homarus, Cullinectes, Gebia, etc., the enrvatures of the individual cornea on both surfaces are very slight; it is biconvex in an extremely small degree. In Talorchestia both surfaces of the cornea are parallel. In Serolis, four species of which 1 have studied, all having well developed eompound eyes, there exists a considerable difference in different species in the nature of the cornea. In some the curvature on the proximal surface is very strong and the whole structure is quite thick, while in others the eornea is rather thin and a slight development of curvatures exists. This is interesting, showing that even within the Eroup of nearly allied species there are considerable diflerences in this respeet.

This fact is easy to understand when we remember the finetional property of the cornea and the crystalline cone. As has been noticed already, the erystalline eone is always dioptric in 
function, whilo the cormen may be partly protective and partly dioptric, or wholly protective. When the cormea beenues partly dieptrie, as in Serolis and in several other Arthropods, the dioptric finntion in an individual ommatidium comes to be pertormed by two structures, the eryatalline cone and the eorneal lens. When the two structures act together fir the same end at the sume time, it is easy to sec how a eertain trivial peculiarity of the one may induce a correlative modifiontion of the other, and how u slight specific peeuliarity may appear exaggerated in the thickuess or in the degrec of eurvature of the corneal lenses in diflerent species.

After so much has been said in regard to the nuity of strueture of the ommatidinm in diflerent $\Lambda$ rthropods, one important point aw:its our eonsideration, viz. the homology and fate of the central ganglion cell found in the ommatidium of Limulus. Unless a great many forms of ommatidia in diflerent Arthropods be compared, a diseussion on this point appears to be unprofitable. The consideration which follows is therefore a purely provisional one.

There ean be no question that the eentral ganglion eell is an important factor in the ommatidinm of limulus, nor can we doubt the existence of a fundamental homology between the retinulae of Limulus and those of all the other Arthroporls which I have examined. With the exeeption of a few problematical bodies, such as the "hyaline cells" of Serolis, there are no struetures in the ommatidia of most Arthropods which correspoud to the central ganglion eell of Limulus, in spite of the existence of a fundament al liomology in the other elements of the onmaticlium.

What has lecome of the eentral ganglionic element of the ommatidiun? Was it lost in the conrse of the phylogenetic history of a more complex ommatidinm? (Or is it rensonable to suppose that some ommatidia eame into existence withont it from the beginning: Or, if it were lost at all, is there any evidenec which makes this supposition probable?

The colorless aranglionic cell and the pigmented rod-bearing eells which surround the former I consider as the two primitive morphological factors in the unit of the sensory part of the Arthropod retina, somewhat in the same way as the circle of 

rods with a cone in the centre are the 1 wo essential factors in the neurerepithelial layer of the human retina. In the absence of enough comparative data in Arthropods at present we have to dwell larguly on the analogy sugresterl in the other gromps of animals. Whatever be the views as to the fundamental homology of the ommatidium of Limulus to a structural muit of the sensory part of the human retina, a superficial resemblance of the one to the other is certainly very strong. The structural resemblanee is paralleled by a physiological one. The place where the light aets in the visual end-organ of Arthropods and of man may alike be considered as consisting of a number of definite groups of cells, eacl group being a morphological and a physiological unit ; or, in other worls, the sensory part of the retine in both eases consist of a mosaic of several sensitive spots. The image formed on such a surface is therefore a mosaic one, whether in an Arthropol or in a Vertebrate.

Fundamental as this arrangement aypears to be in the luman retina, these two factors are liable to rariation in their relative distribution in different Tertebrates. In fact, the variation takes place between the two extremes where the rorls alone exist on one hand and where the cones alone constitute the essential part of the retina on the other. Thus, aceording to Schultze, "either form of pereipient element (rod and cone) may be represented by the other" in the Vertebrate. This range of variability in the distribution of the cones and rods oecurs even in a single group of Vertebrates, as in mammalia, showing that the variation in the distribution of the essential factors, even within a tulerably well circumseribed group of animals, is sometimes qnite extensive. 'The group of Arthropods is a heterogeneous one, and I see no a priori oljection to believing in the existence of a plenomenon analogons to what we find in Vurtebrates, riz. that the two percipient elements represented by the central and the peripheral cells in the ommatidimm of Limulus may be differently represented in different Arthropods.

There is no donbt whatever that the retinnla cells are homologons thronghont the Arthropods. In fact, in most Arthropeds which I have examined no other elements but the retinulae have any ernnection with the optic nerve fibres, and they often undergo an enormous development and aequire most eomplieated 

structures, as in llomarns or in Penceus, giving rise to the much discussel "spindle."

But what has become of the eentral element which is so conspicnons in the ommatidimu of Limulus, if the retinnlae in all Arthropods are hunologons? I believe the central cell is fully functional, judging from its position and from its reritable connection with optic nerve fibre in Limulus. What in other Arthroprods strongly reminds one of this cell is the "liyaline cell" at the buttom of the ommatidial pit in Serolis and, aceording to Beddard, also in the C'ymothoidae. One important diffirence, however, exists between the "hyaline cell" of the Isoporls and the central cell in the ommatidinn of Limulus, viz. that, while in the latter the cell is connected with the optic nerve, the "hyaline cell" in the former has no connection with the central nervons system whaterer. Hence the "hyaline eell" cannot be sensory, even if it he homologons with the central cell of Limulus, which it resembles in its general appearance and in its position. The number of "hyaline cells" in serolis is always two, while. its supposed homologne in limulus is, as a general rule, only one. This fact does not offer any oljeetion to my view of their homology, when we bear in mind that other elements in different ommiatidia, as vitrellae and retinnlae, show a wide range of variation so far as their numbers are concerned, and yet they can be considered as perfectly homologons.

A further embryological and comparative knowledge in regard to the "liyaline cell" in Isopods is necessary for the determination of its exact homolngy. Meanwhile I wonld observe that if the central and the peripheral cells which we see in the ommatidinm of Limulus may be taken as the two essential factors of the sensory element of the typical Arthropod retina, the ease of Serolis may be taken as a loss of balanee in the relative development of these $t w n$ taetors; the rentral eclls having lost their sensory function and remaining as a sort of supporting mechanjsm. We can imagine this change in the function of the central cell as carried still further, and with the exeessive development of the prripheral elements, the retinulae, the central element may finaly have disajpearetl.

All this is, however, a mere suggestion, and my interpretation of the nuture of the Arthropod ommatidinm in general does not 
Juse its foree even if this section of my views in regard to the fitte and lomology of the central cell of cells be proved nutenable. It is qnite possible that the ommatilia in which there is no element eorresponding to the eentral cell of Limulus may have origninated withont it from the boginning. It seens, however, more natural to suppose that sueh an ommatidiun had it originally and lost it later, ohserving that the simplest form of ommatidium possesses it in its fully functional, sensory form.

Finally we lave to comsider the nature of the compound eye as $\mathrm{u}$ whole as presented in varions types of Arthropods.

That a certain structure in the body of an animal may repeat itself and give rise to a secondary aggregate, or to a compound organ, is a well known fact; the repetition of similarly constructed miniferons tubnles forms the essential part of a vertebrate kidney, or the similar repetition of gill-filaments forms the respiratory organ of a Lamellibraneh. Sundry other examples of this nature might be griven, but the above two will suffice. Traeing, as I have attempted to do, the most complicated ommatiditum into a simple, open ectodermic pit, there is to my mind no difficulty in betieving that the componnd eye of the Arthropod is one of the most astonishing examples of the formation of an organ by the vegetative repetition of the similar structure. Thns, according to Lubbock, there are abont 4000 facets in the compound eye of the liouse-fly (H/usca), each ficet corresponding to a single tubular invagination of the skin, the ommatidium. There are 4000 independent invaginations in the area in the head of the fly ocenpied by the compound eye; in the garlfly (Estrus) 7000 ; in the goat-moth (Cossus) 11,000 ; in the deatlis-head moth (sphinx atropos) 12,000 ; in a butterfly (I'upillio) 17,000 ; in a dragon fly $($ Eschna 20,000 ; in a small beetle (Homlella) as many as 25,000 . On the other hand, the number of ommatidia seems to have reached its minimum in certain (inpepods, as in Corycuns, where the whole visual organ seems to be represented by a single colossal ommatidium.

Certain forms of Collembola ${ }^{1}$ seen to have a very small num-

'Lubbock. Monograph of the Collembola and Thysunura, the Ray Society, 1873, p. 57, Pls. LV and LVI. Lubboek uses the term "ocellus" to designate a single element of the eye whieh I here called an ommatidium. If the structure of this "ocellus" differs from the ommatilium of other Arthroprods, it has, of eourse, nothing to do with the disenssion at issue. 

ber of ommatidia; thus in Templetenia only one onmatidium exists on each side of the head; (1rcheselle has six on earh side of the head: Timoceres, Lsoprome, have seven; Deveeriu, Lepidecyrtus, simynlleurus and I'tpirius, eight. In the muls we observe a similar wradation in the number of ommatidia.

What reasons cun we assign for this cnormous multiplication of similarly constructed parts? What alvantage follows from this arrangement? If the view of the nature of the componnd eye which is put forward in the preceding pages be a truc one, Miiller's celebrated theory of mosaic vision is the only one that can aceount for the enormous multiplication of the simularly tormed pits in the skin. The subject has been so finlly discussed by Lnbbock that I need not enter into details here. "Acording to his (Johannes Mïller's) view, those rays of light only which pass directly through the erystaline cones, or are ruflected from their sides, reach the eorresponding nerve fibre. The others fall on and are absorbed by the pigment which separates the different facets. Hence each cone receives light only from a very small portion of the field of vision, and the rays so received are collected into one spot of light. The larger and more convex, therefore, is the eye, the wider will be its field of vision; while the smaller. and more numerous are the facets, the more distinct will the vision be. In fact, the picture perceived by the insects will be mosaic, in whieh the number of points will correspond with the number of facets."1 The whole explanation of the problem seems to me to be contained in the passage above eited; and no firther comment will be necessary more than a statement that the increase in the number of ommatidia is a decided advantage to their possessor. An eye like that of Limulus might by a slight change be converted intu one of a more protuberant nature so as to command a wider field of vision, as we see in some epecies of Serolis or in sone Trilobites; a slight change again might produce a protuberant ocular area monuted on an ophthalanie stalk, and accompanied by the acessory apparatus of vision, such as the socket for protection or the set of museles to move the eye-stalk in different directions so as to command a still wider fichl of vision. In this connection I may refer to a series of diagrams (Figs it-sl, Pl. XXX V). The black heavy layor repre-

'Lublock: Senses, Instinct and Intelligence, p. 163. 

sents the ectoderm, and the region in which the ectoderm is thrown into folds the area of the compound eye. The yellow colored layer outsile represents the chitin, and the dotted line beneath the cetolerm, the basenent membrane.

In Limulus (Fig. 74 ) the ectoderm is thrown into a series of shallow folds, which, when viewed from above, would he a group of shallow pits in the skin. Each pit is an ommatidium. In Serolis (Fir. 75) the invagination of the skin is a little deeper than that of Limulus, and the whole ocular area is more prominent. Fig. 76 represents the condition of the ectollerinal folding in Nutonecta, and Fig. 77 that of Agrion larva. Fig. 78 represents the eye of Bronchipus, only a part of the stalk being shown in the figure. Fig. 79 represents the eye of Cambarus; Fig. 80 that of Penaeus, and Fig. 81 that of Lucifer.

It must not be understood that the number of folds given in the diagrams have anything to do with the actual number of ommaticlia that may exist in the actual specimens; no more than a morphological expression of the eye in a simplest possible form was intended. If one suppose a single invagination of the skin, say of Fig. 79, be divided into three strata and the eells in the bottom stratum to send ont nerve fibres, those in the middle to form the erystalline cone and those in the outermost to form the cornea (Fig. 71), the interpretation of the diagram will be complete.

According to this view the componnd eyes of Arthropods, either in the sessile or in the stalked form, are nothing more than a collection of ectodermic pits whose onter open ends face towards the sources of light, and whose inner ends are connected with the eentral nervous system by the optic nerve fibres. The cells forming the walls of the pit arrange themselves inte three strata, in most cases accompanied by three regional functional differentiations. Grenacher's classification of the componnd eyes of inseets into "acone," "psendocone" and "encone" types reters to the condition of the cells and their products in the middle stratnm-the vitrellae.

Morphologically, then, the compound eye of an Arthropod is strictly single-layered, although, as is evident, the present conception is entirely different from the monostichous theory maintained by some reeent writers. From Limulus to Squilla we 
have a series of forms slowing all dewrees of modification in the gencral strueture of the eye as well as the structure of its indivilual elements, and there is not here a single form which invalidates the view maintained in the present paper. Horcover, this view has the advantage of greatly simplifying our eoneretion of these structures, redueing, as it does, all of them to onc primitive structure, a depression in the skin, in which several organs of ectodemal nature, often of a very eomplicated type, find their eommon morphologieal origin. And when thes the nature of the unit is redued into a simple invagination of the skin, the formation of the compound eye appears to be but another instance of the well known method in the formation of a morphologieal organ, namely, the vegetutive repetition of a similar structure.

\section{V.-SUMMaRY.}

In studying the strueture of the ommatidium of the eomponnd eye of Serolis it has becu found that it may be relnced to a simple ectodermic invagination of the skin. Extending my researelies over several other Arthropods, of whieh Talorehestia, Cambaru, Homarus, and Callinectes were mentioned in the proceding pages, the same interpretation of the ommatidium may be applied without exception. This view of the ommatidium finds its strongest support in the fact that in Limulus, the oumatidium is an open pit of the skin.

By supposing that the ommatidial pit of Limulus beeame deeper and that this was aecompanied by modifications in the structure and arrangement of the component eells, we ean show the probability of our first supposition that the ommatidium of the eomponnd eye of" an Arthropod is an independent invagination of the skin. If this view is correct, the unit of the eompound eye of an Arthropod is not, after all, so eomplex a strueture as has been supposed by some; and the enormons inerease in the number of ommatidia in a giren area of the skin which results in the formation of the compound eye fincls its parallel in the well known method of the formation of morphologieal organs, viz, the duplication of a simple unit.

Baltimore, April 30, 1889. 


\section{YI-ATPEDIX. \\ The Compound Eye of Erhinoderms.}

While the preceding paper on the compound eye of Arthro, pods was passing throunh the press 1 improved my appor tunity to stndy the compound eye of Echinolerms at Woods Iloll, during the months of June and July, 1sis?, to see bow tar the morphological interpretation advanced for the former will hold to the latter.

The three starfishes common at Woods IIoll, viz. Asterias. vilgaris, Stimp., Asterias forbesii, Verril, and C'riluellu sanguinolenta, Lutken, were studied in this comnection. While I reserve the description of the details for a future paper, I will briefly point out some important bearings of the results upon the subject which has been discnssed in the preceding pages.

The general structure of the compound eye of the startish at the tip of each ray is well known through the writings of Hexckel. W'ilson, Hotlinamn, Lange, Greeff, Hamann, ('arrière, and some others, although there exist some discrepancies in regard to the histological features of the organ as described by these naturalists.

The most remarkable observation on the eye of the Echinoderm among the early writers is that of Goodsir, who, according to Forbes, ${ }^{1}$ is said to have examined the eye of Cribelle orulate and remarked of its strueture that it eonsisted "of" a red cus hion with pits on its surfuce." My studies on the compound eyes of the starfishes eonvinced me of the truth of Goodsir's statement, and the eye of a starfish is nothing more than a group of ectodermal conical pits with their bases turned towards the exterior. The epithelial cells which form the walls of the eonieal pit have each a euticnlar rod secreted at the tip of its distal extremity.

These cells send out nerve fibres from their proximal extremities. In the centre of the pit along the longitudinal axis of the invarination there is a space filled with a clear fluid substance. The cuticular secretions of the retinal cells, as well as the colorless fluid substance, constitute together a translueent

'E. Forhes: A Iristory of British Starfishes, and other Animals of the class Echinodermala. London, 1841 , p. 102. 

refractive body in the centre of each pit or the ommatidium, which has been described by several as the "erystalline enne" in thestartish eye. The whole surfiue of the eye-bulb is covered by a thin cuticle which is seereted by the cells whose distal extremities lie on the general level of the external surface of the optic bulb. In short, this external cutieular covering of the eye in a startish corresponds to the cornea, and the enticular secretions at the distal extremities of the retinal eells forming the walls of the pit, correspond to the crystalline cone and the rhellotom of the eompound eye of an Arthropod. The eolorless fluid sulstanec eontained in the axial space of the invagination in the starfish may be compared to the similar substance in the erystalline cone of the ommatidium of Serolis. The number of onmatidia in the startish inereases at the periphery of the optic tract as in an Arthropod. The spaces between the adjarent ommatidial invaginations are ocenpied by the supporting epithelial cells. The optic nerve fibres pass into the deepest stratum of the epithelial layer, and running horizontally, join the main branch of the ventral nerve eord of the ray.

On the whole, the entire morphologieal arrangement of the parts in the compound eye of an Echinoderm is strikingly similar to that of an Arthropod, and the formation of the visnal organ in the Echinoderms, at least in one of the large sul-groups, the Asterida, by a series of ectodermic invaginations, assumes a wider significance when we take into consileration the fict that the eompound eye of the Arthropods has a similar mode of origin, although it is an independent adaptation.

In the anatomical consideration of the Eehinoderm eye I have made no allusion to the so-ealled "eye-spot" on the ocular plate of the sea-urelin. In regard to the function of this structure we are by no means certain that it is visual in nature as it is usually assumed. Valentin failed to discover any traee of dioptric apparatus in it. Hore recently Frederic ${ }^{1}$ could not find any evidence, anatomically and experimentally, that the structure in question is an eye. "La tuche de pigment qu'on y decrit est une pure fiction."

'Fredericq, Léon: Contributions il l'ilule dex Echinides. Archives des Zoologie Experi, et Gener., Tome 5, 18;6, p. 434. 
Il amann, who studied this structure in Echimus, declares that the so-called "eyo-kpot" in the sea-urchin bears a close resemblance to the terminal feeler at the tip of arm of $n$ starfish, with which he thinks it is homologous and not with the eye. II therefore substitutes the term "intergenital plate" for the "ocular plate" upon which this problematical organ rests.

Even if this organ be shown to have some connection with the visual function, as Romnnes and Ewart ${ }^{2}$ claim on the gromnd of their experiments, it is sate to say that it belongs to a different categrory of visual organ, as Ilamann's histologieal study elearly shows, and has nothing to do with the subject under our consideration, viz. the morphology of the compound eye of the Echinoderm and the Arthropod.

Entirely apart from the preceding, but which may be mentioned in this connection, is the Sarasins' discovery ${ }^{8}$ of the componnd eyes in a sea-urchin (Diadema) from Ceylon. Of their risual nature there can be no doubt, as their experiments on the living animals as well as the anatomical structure of the eyelet show.

The eyelet of the compound eye in Diadema is very mueh more complex than that of the starfishes I have examined. I eannot help but believe that a study of development of such an interesting form as Diadema, as well as a more extensive study of the eve in different yenera and species of Echinoderms, will throw a great deal of light on the morphology of the compound eye in general.

In iny main paper on the subject $I$ hope to describe in detail the structure and development of the compound eye of the starfish that I have studied, and also to give an aceount of the growth of our knowledge of the visual organ of the Echinoderms, both anatomical and experimental, from Tiedman and Ehrenberg down to the present day.

'Llamann, Otto: Beiträge zur Hislologie der Echinodermen. Jenaische Zeitschrift fur Naturwissenschaft, Bd. 21, 1N87, pp. 124-126.

'Romanes, J. G., and Ewart, J. C.: Obseriations on the Locomolor System of Echinodermata. Philosophical Transactions, Royal Socicty, London. Pt. III, 1881, pp. 855-856.

"Sarasin, P. B. and C. F.: Ueber einen mit Zusammengeselzlen Angen bedeckten Seeigel. Zoologischer Anzeiger, 8 Jahrg. No. 211, 1885 . Their main puper I have not seen. 



\section{ViI.-Explanation of Figures.}

\section{List of Reference Lettcrs.}

Ap. Appendage.

Ax. p. Axial process of the ganglion cell.

li. M. Basement membrane.

$C$. Corneal lens.

$c$. Cormen or corneal ficet.

c.c. Crystalline cone.

Ch. Chitin.

c.g. C'orneagen.

d.f. Dorsal fold.

D. O. Dorsal organ.

F. Eye (compound).

Ect. Ectorlerm.

Ent. Entosternite.

Ep. Epithelial cell.

F.y. Food-yolk.

$G$ G. Ganglion cell.

II. Hyaline cell.

$L$. Lens-cone.

M.s. Mesolerm.

I. Nucleus.

Oc. Ocellus.

Om. Ommatidium.

Op.n. Optic nerve fibre.

p.c. Packing cell.

p. $n$. Perineural cell.

Pg.c. Pigment cell.

Pg.p. Pigment patch.

$R b$. Rhabdomere.

Rt. Retinula.

Tr. fb. Transverse striae.

$V$. Vitrella.

V.C. Ventral nerve chain.

v.f. Ventral fold.

$x$. Axial space or line of the onmatidinm, corresponding to the cavity of the invagination. 
Phite XXIX.-Serolis, Talorhestia, Cambarus, Callinectes and Limulus.

FIG. 1.-Sirolis. Two ommatidia of Serolis: the one on the left with the pigment cells enveloping the errstalline cone. The downward extensions of the rhablomeres reach to the retinal side of the basement membrane. $\frac{1}{2}(\mathrm{E} \times 2)$ Keiss.

Fig. 1a.-Serolis. Diagram of the Onmatidinm-
a. Corneagen.
1. Cornea.
b. Vitrella.
2. Crystalline cone.
c. Retinula.
3. Lihabdomere.
d. Hyaline cell.
Pg.c. Pigment cell.

FIG. 1b.-Serolis. Plan of the Ommatidium-
1. Ilyaline cell $(d)$.
4. Corneagen $(a)$.
2. Retinula (c).
5. Pigment eell (pg.c).
3. Vitrella $(b)$.

FIG. 2.-Morphologieal diagram of the ommatidium of Serolis-
a. Corneagen.
1. Corneat.
b. Vitrella.
2. Crystalline cone.
c. Retinula.
3. Rhabdomere.
d. IIyaline cell.

Fic. 3.-T'torchestia. Ommatidium of Talorchestia.-Rt', upward extension of the retinula $R t$; this upward extension sometimes reaches as far as the cornea. p.c. Narrow, nou-pigmented packing cells. $\left.\frac{1}{2}(1) \times+1\right) \mathrm{Z}$.

FIg. 3a.-Talorclestia. Plan of the Ommatidia.

Fig. 4. Cambarus. Three ommatidia shown side by side. In $c$ the pigment cells ( $p g . c$ ) completely envelop the erystalline cone. $x$ is the morphological lumen of the invagination. $E p$ is the epithelial cell charged with light yellow pigment granules. $\left.\frac{1}{2}(1) \times 2\right) \mathrm{Z}$.

Fic. 5. Callinectes. 'Two ommatidia shown side by side. Rhabdomere $(R b)$ shows a fine striation. At the swollen end of the retinula $(R t)$ yellow or brown colored globules are foumd.

Fis. 5a.-Callinectes. Head of the retinulae more highly magnified, and the rhabdomeres show slight enlargement at the terminal portion.

FIG. 6.-Limulus. Two ommatidia shown side by side, partly schematic. The thick yellow-colored body is the chitinons covering of the eye. $L$. lens-cone, fitting into the depression of the skin. At the bottom of the depression, the essential part of the ommatidium 

is found, consisting of two parts, $R f$ (retinulae) and $f$ (centrul gang lion cell). Cells forming the walls of the pit are the perinenral cells $(p, n)$. Inward prolongations of the neuro-epithelial cells (Lit and $G$ ) form the optic tibres $(O p, n)$. M. Mesodermic tissue.

Fro. Gu.-Limulus. Trunsverse sections of five ommatidiat ut different levels. In $(a)$ the plane of section passes through the npper part of the depression, cutting the less-cone $(L)$; in $(b)$ the section plane pusses through the retinulae, showing the star-shaped rhabdom and the axial process of the ganglion cell $(A x . p)$ in the axial canal of the rhabdom. I few pigmented perineural cells surround the retinulae, while the basement membrane $(B, V)$ forms the complete capsule of the ommaticlium, separating the latter from the mesolermic tissue $(. / / s)$. In $(c)$ the plane of section passes through the lower part of the ommatidium, cutting the central ganglion cell $(G)$; in $(d)$ the ganglion cell oceupies an eccentric position; in $(e)$ the sections of optic nerve fibres alone are seen.

FIG. 7.-Limulus. Plan of the ommatidium. Ep represent the cells which are found in the walls of the pit; the yellow edge corresponds to the surface where the chitin is secreted.

\section{PLATE XXX.-Limulus.}

Frg. 10. Retinula $(R t)$ and ganglion cell $(G)$ teased out from the onmatidium after treatment with IIaller's fluid 15 hours. The axial process $(A x, p)$ of the ganglion cell closely follows the external border of the rhabdomere $(R b)$. A number of epithelial cells arc found closely attached to the surface of the retinula as well us to the ganglion cell. $\frac{2}{3}(\mathrm{E} \times 2) \mathrm{Z}$.

FIG. 11. A bunch of retinulae completely isolated from the ommatidium. l'igmented epithelial cells $\left(E_{p}\right)$ are found between them. The proximal ends of retinulae form the optic nerve fibres $(O p . n) . \quad \hat{3}(\mathrm{E} \times 2) \mathrm{Z}$.

FIt. 12. A retinula cell seen from the side opposite to the rhabdomere. A number of extremely attenuated epithelial cells $(E p)$ are found closely clinging to the exterual surfice of the cell. They do not form any connection with the retiunla, and can be completely isolated from it. The eell-body of such an elongated epithelium is rednced to a very slender filament and does not contain any pigment grutules. $\ddot{3}(\mathrm{E} \times 2) \mathrm{Z}$.

FIt. 13. The central ganglion cell with its axial process (.1.x.p) completely isolated. The piganent patch $\left(l^{\prime} y \cdot p\right)$, situated between 

the nucleus $(.1)$ and the optic nerve fibre $(O p, n$, shows a eharacteristic mark of the cell. $\Lambda$ zone around the nuclens $(\lambda)$ shows concentrie narkings. Longitudinal striae run through the axial process and the optic norve; $(E p)$ an attenuated epithelial cell. $3(\mathrm{E} \times 2) \mathrm{Z}$

Fiti. 14. Another type of the central ganglion cell. Pigment pateh is greatly extended; mueleus $\left(X^{\prime}\right)$ is eccentric; $(E p)$ attenuated epithelial cells. $3(\mathrm{E} \times 2) \%$.

Fia. 15. The central ganglion cell, with its axial process $(A x, p)$ divided into several branches, by some nechanical carses. All these branches are longitudinally striated like the main one and would seem to be male up of a collection of extremely fine longitndinal fibrils. Two pieces of chitinons body $(K b)$ are found at the junction of the axial process and the cell-boly proper of the ganglion cell. They appear to be fragments of the rhabdoneres. $3(\mathrm{E} \times 2) \mathrm{Z}$.

The specimens fignred in Figs. 10-14 were treated with Ilaller's macerating fluid; that shown in Fig. 15 was treated with sulphuric acid, 8 drops to 30 grams of water.

Fig. 16. Epithelial cells isolated from the margin of the ommatillial depression. 'The part in which there is no pigment is turned outward and comes in direct apposition to the chitin.

Plate XXXI.-Limulus, Homarus, Cambarus, Squilla, Callinectes, Serolis.

Figs. 17-33.-Limulus. This series of specimens is intended to show the range of modification of the epithelial cells fonud in the ommatidium and its direct neighborhood.

Fic. 1\%. Central ganglion cell with several attenuated, nonpigmented epithelial cells. $\frac{2}{3}(\mathrm{E} \times 2) \mathrm{Z}$.

Frg. 18. Retinula cell with a few pigmented epithelial cells at its side. $3(\mathrm{E} \times 2) \mathrm{Z}$.

Figs, 19-33. Ordinary epithelial cells isolated from the ommatidial region. $\frac{2}{3}(\mathrm{E} \times 2) \mathrm{Z}$.

Fig. 34.-Homarus. Retinulue partly isolated. Each retinula secretes a chitinons boly which assumes a serrated appearance $(R b)$. 'This is the rhabdomere; when the hundle is bronght together it assumes a spindle shape. The upper part of each retinula cell is free from pigment, and is connected with the pigmented portion by a loug, slender neck. The nuclens of the retinula is situated at the nou-pignented, distal extremity. $\left.\frac{\pi}{3}(1) \times 2\right) \mathrm{Z}$. 

Fis. 35.-Cambarus. The retinula completely isolated. The rhubilomere shows a coarse wavy ontline. if 1) $\times$ z) $\mathrm{Z}$.

Fı, 36.-Squilla, partly diagrumatic.

Fro. 37.-C'allineetes, purtly dingramatic.

Fic. 3s.-Serolis, purtly diagramatic.

The last three ligures are introduced here 80 as to show the homology of the retinula cells in different groups of Arthropods.

All the specimens figured in this plate were treated and macerated in Haller's fluid.

\section{Plate XXXII.-Limulus.}

Fig. 39. Young embryo of Limulus. D. O. "Dorsal organ"; * shows the position where the componnd eye makes its appearance. Frg. 40. Larval Limulus in the so-called "trilobite stage"; immediately after hatching. D. O. "Dorsal organ"; $E$. Compound eye; Oc. Ocelli.

F1G. 41. Young Limulus at the first stage in the acruisition of the external Limuloid characters. The whole body is transparent and the dendritic ramifications of the "liver" shining through the transparent tissues of the body. The "dorsal organ" has completely disappeared in this stage. $E$. the compound eye; and (Cc. Ocelli.

Fig. 42. Transverse section of a young larra, showing the origin of the compound eye $(E)$, the formation of the dorsal and rentral folds of invagination (d.f and $v . f$ ), and the "dorsal organ" $D . O$. $3(\Lambda \times 2) \mathrm{Z}$.

Fic. 43. Transverse section of the compound eye, showing the formation of the optic nerve fibres by the migration of the ectodermal cells. $\frac{\hat{n}}{3}\left(\mathrm{D} \times \frac{1}{)} \mathrm{Z}\right.$.

FIG. 4t. Outline of the thickening of the nerve plexus beneath the ommatidial layer. $3(\mathrm{E} \times 2) \mathrm{Z}$.

IG. 45 . The sume. $\frac{n}{3}(D \times t) Z$.

Both are drawn from the gold-chloride preparations.

FIg. 16. Ganglionic swelling found in the optic nerve fibres of the median eye. $3(4 \times 1)) \mathrm{Z}$.

\section{PLiTE XXXIII.-Limulus.}

Fig. t.5 2 . Longitudiual section of the eye, showing the formation of the optic nerve fibres $(0), n)$.

Fici, $t$ fra. Oblique longitudinal section of the eye, showing the formation of the optic nerve fibres $(O p, n)$. 

Fas. 47-56. Consecutive series of transverse sections of the compound eye of Limulus at the beginning of the lateral invatgintions. Fig. 47, No. 1; Fig. 48, No. 3; (the section No. 2 is essentially the same as No. 3). Fig. 49 , No. 4; Fig. 50, No. 5; Fig. 51, No. 6; Fig. 52, No. 7 ; Fig. 53, No. s; Fig. 54, No. 9; Fig. 55, No. 10; Fig. 56, No. 11. The lateral invaginations become distinctly marked at Fig. 49, No. 4, and fuse in the median line at Fig. 54, No. 9, forming the median fold $(m . f)$.

\section{I'LATE XXXIV.-Limulus.}

Fiss. $5 \%-64$ show the condition of the lateral and median invaginations of the compound eye in the stage shown in Fig. 41, Pl. IXIII.

FIG. 5\%. In this the plane of section passes through the anterior part of the eye, and the dorsal invagination $(d . f)$ of the compound eye is distiuctly shown. The skin is thrown into folds; into the concave lumen of the fold a slightly thickened portion of the cuticle fits, forming the rudiment of the lens-cone $(C)$; and the cells forming the walls of the invaginated fold form the beginning of the ommutidium.

Fig. 5s shows the widest portion of the eye in this stage; the beginning of the ventral invagination $(v \cdot f)$ is distinctly recognizable. The dorsal fold $(d . f)$ is very large. Four distinct ommatidia are formed in this section, each depression being accompanied by a slight thickening of the corresponding portion of the cuticle $(C)$. The basement nembrame is very distinetly seen underneath the ocular area and beneath the general ectoderm cells which lie outside of the ocular area. The action of acid to which the sections were subjected in order to remove the pignent gramules has interfered with the preservation of the ectodermal cells in those regions, although the thick, refractive basement mombrane remains quite distinctly,

FIGs. 59, 60 and 61 show how the lateral invaginations are gradually approaching as we go towards the posterior part of the eye. In Fig. 62 the dorsal and ventral folds $(d . f$ and $v . f)$ meet in the median lne, and in Fig. 63 they form a complete tube, the granular, non-pignented layer coming to the ontside and the pigmented cell layer $\left(I^{\prime} g . c\right)$ occupying the deeper jart of the tube. 'The basement membrane ( $B . S$ ) forms a complete cajsule around the tube. The basement membrane which underlies the general ectoderm comes to 
the ontside of the median fold (m.f). Counting from the outside we meet with three consecutive stratit of basement membrane in this region of the ere.

Fit. 64. In this we come nearly to the posterior extremity of the median fold $(m, f)$. The median fold is further from the surfuce basement membrano than in Fig. 63.

\section{PLATE XXXV.}

Figs, 65-699. Diagrams showing the probable evolution of the three-layered ommatidium from the single-layered surface depression in the skin, by the gralunl subsidence of the neuro-epithelial elements, $R$ t and $G$, Fig. 65. In Fig. 66 the ommatidinm of Limulus is represented, which is considered a step further advanced from the condition shown in Fig. 65. The distal end of the retinula $(R t)$ instead of being pointed toward the exterior as in Fig. 65, in Limulus it points towarls the median axis of the oumatidium. The chitinous substance being still secreted on the ontside, a distinet boly of ehitin beneath the lens-eone $(C)$ is formed, the rhabelom ( $l i b)$. In Fig. $6 r$ this deepening is supposed to have gone still further, resulting in the formation of another independent ehitinous body, the erystalline eone $(C, c)$. In Fig. 68 this deepening is considered to have advanced still further, the crystalline cone $(C, c)$ being entirely separated from the eorneal lens $(C)$ by a distinct stratum of cell, the corneagen $(c . g)$. In Fig. 69 an ommatidium with three strata of cells, each seereting chitinous substance on the part of their surface, is formed. These three strata of cells are known as the corneagen $(c, g)$, the vitrella $\left(\Gamma^{*}\right)$, and the retinula $(R t)$. Three chitinous bodies secreted by each group of eells above mentioned are the cornea $(C)$, the crystalline cone $(c \cdot c)$, and the rhabdomere $(R b)$, respectively.

FIG. 70.-Serolis. Diagram of the ommatidium of Serolis. General arrangement of cells in this is not very different from that shown in Fig. 69. The place of ganglion cell in Fig. $69, G$, is taken by a pair (of which only one is shown in the diagram) of transparent "hyaline cells" (II).

Fif. 71.-Crembarus. This is introdnced in comparison with the hypothetical ommatidia.

Frg. 72.-Callinectes.

Fic. 73.- Tulorchestia.

In the last three forms no element corresponding to the central 

gunglion cell of Limulus nor to the "hyaline cell" of Serolis can be found. The sensory element of the ommutidium is represented by the retimulae $(R t)$ only.

Fig. 74.-Limulus. Dingram of the componnd eye of Limulus, the black, heisy line representing the ectoderm and each depression in this laver corresponding to an ommatidium.

Fig. 75.--Serolix. In the same way as the above, the eye of Sorolis may be represented by a series of lolls.

FIG. 76.-Notonecta.

Fig. 7\%.-Agrion (Larva).

Fig. 78.-Branckipus.

Fig. ₹9.-Cambarus.

Fig. 80.-Penaeus.

FIG. 81.-Lucifer. 


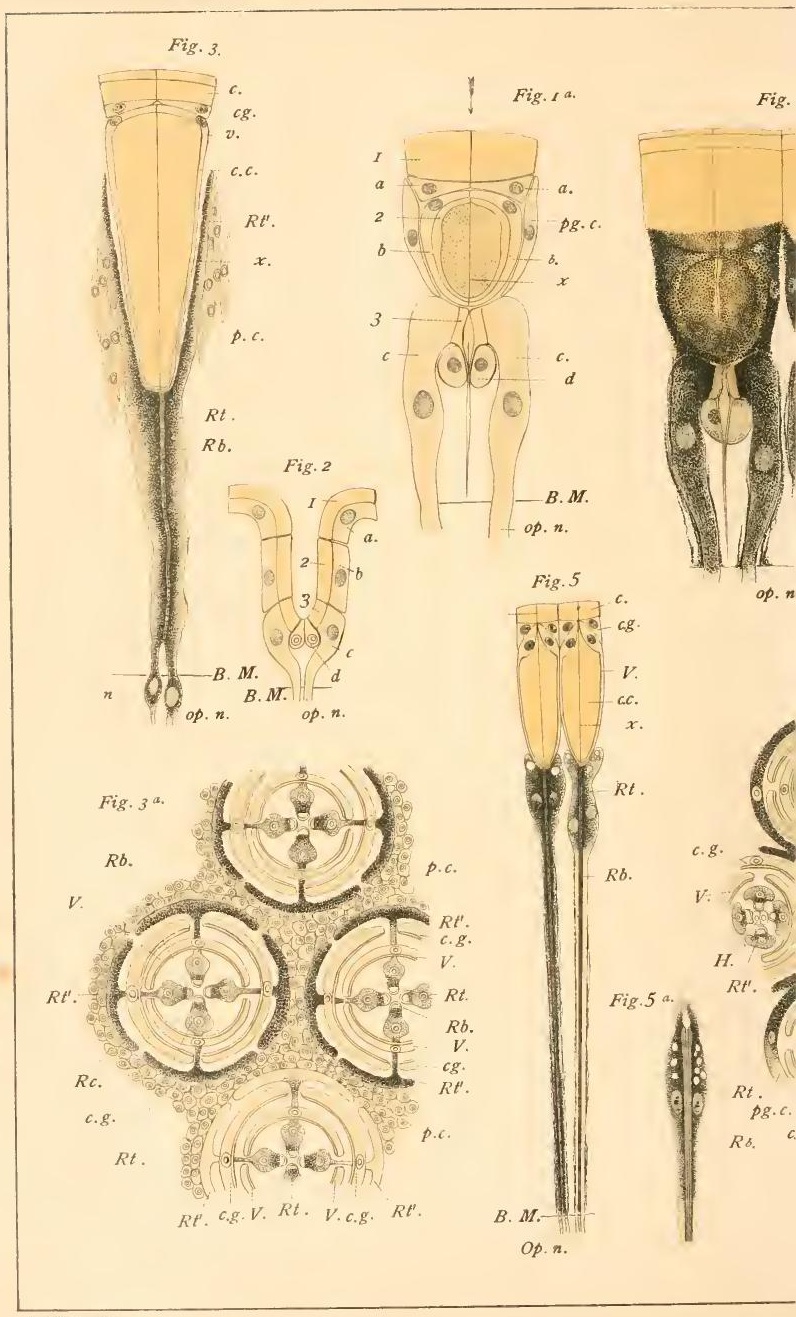




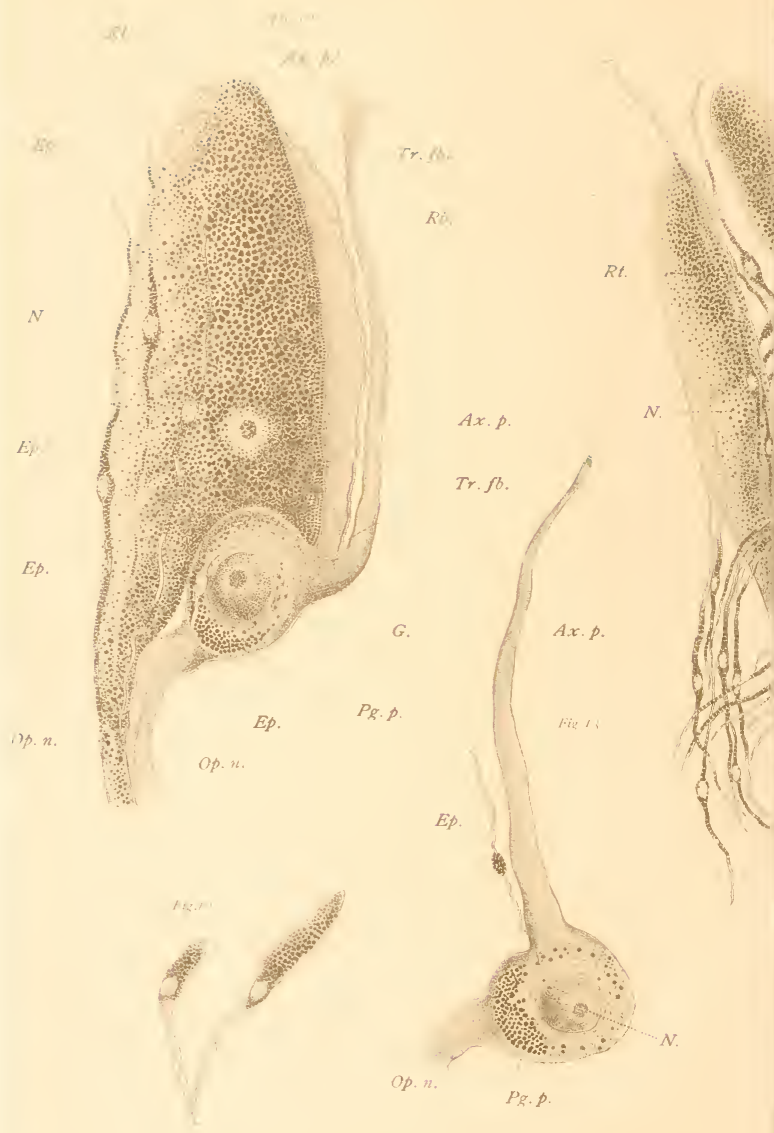




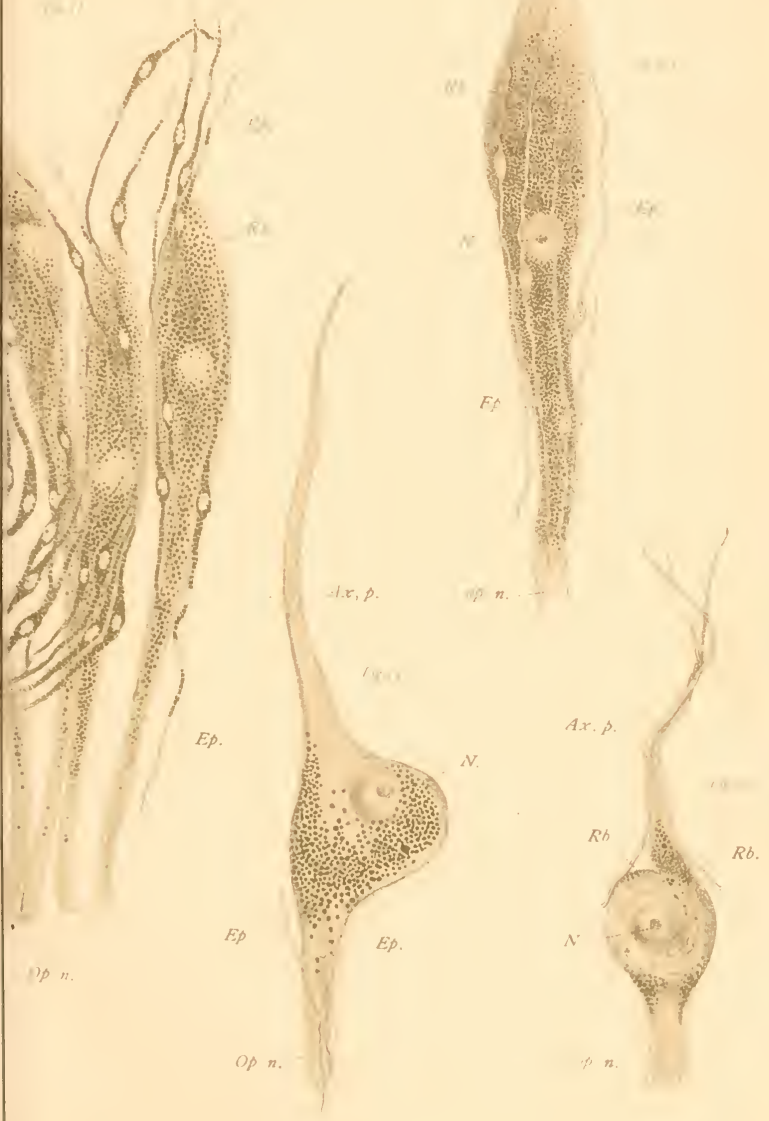




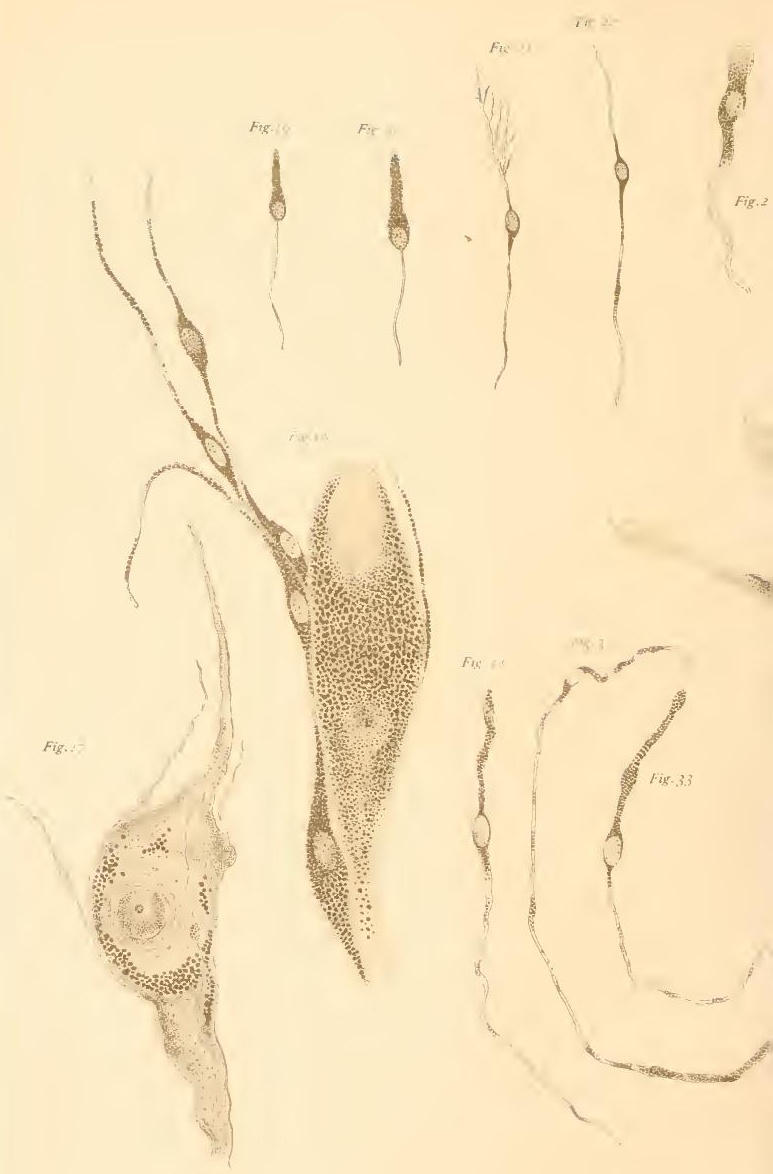




$$
\begin{aligned}
& 11 \\
& 6111
\end{aligned}
$$


Fix

Hig. 4.

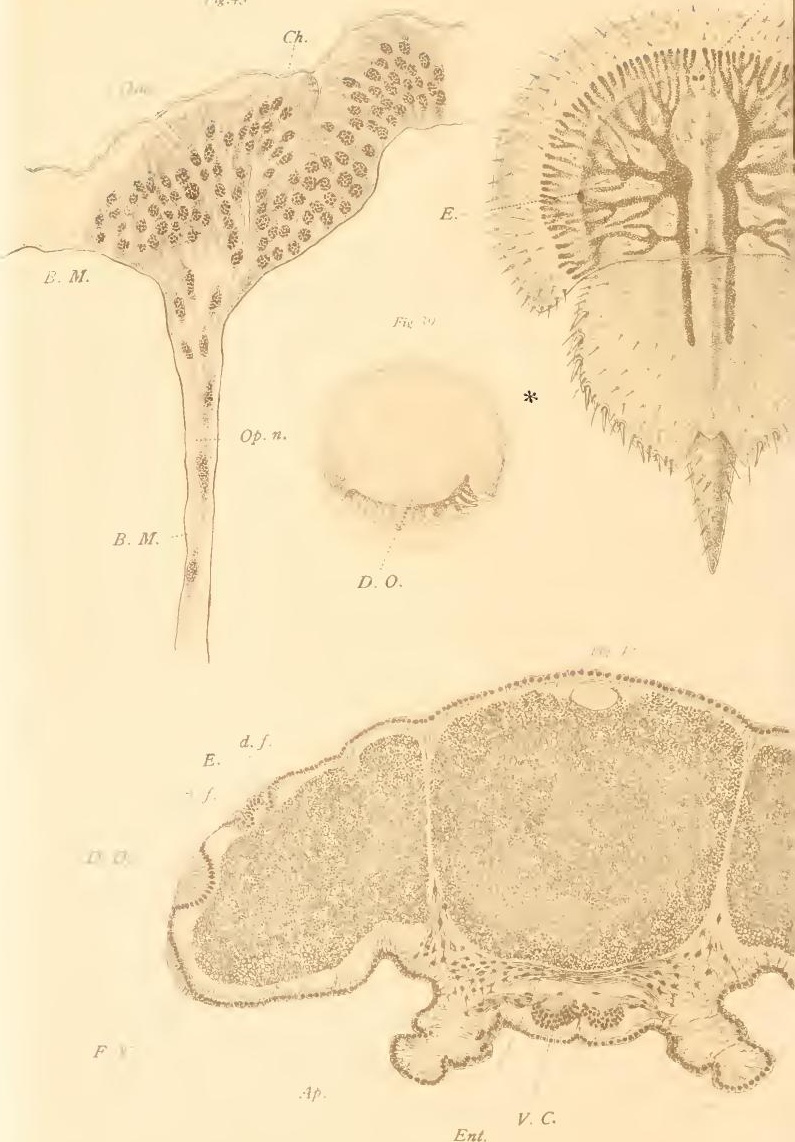





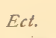

et.
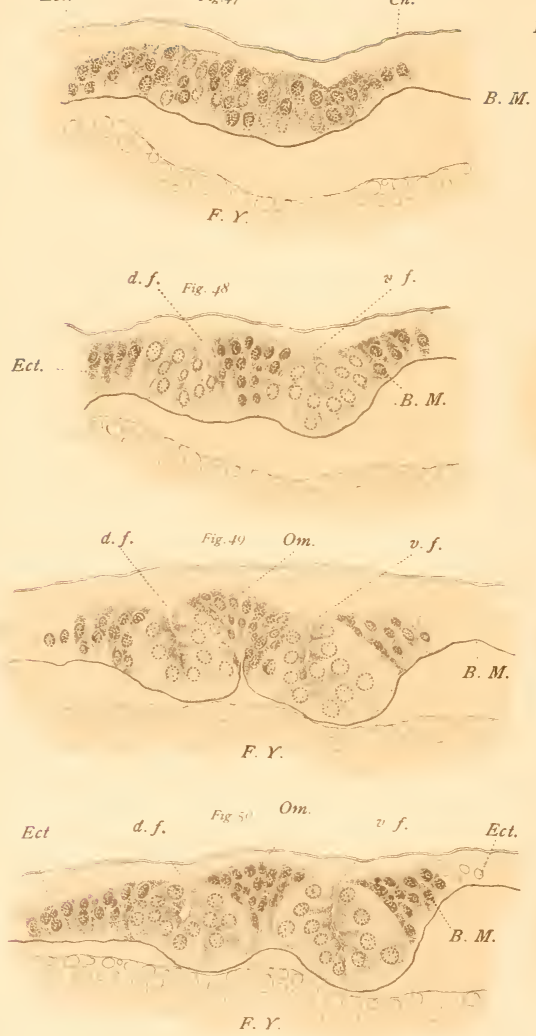

Ect.

P.

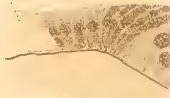




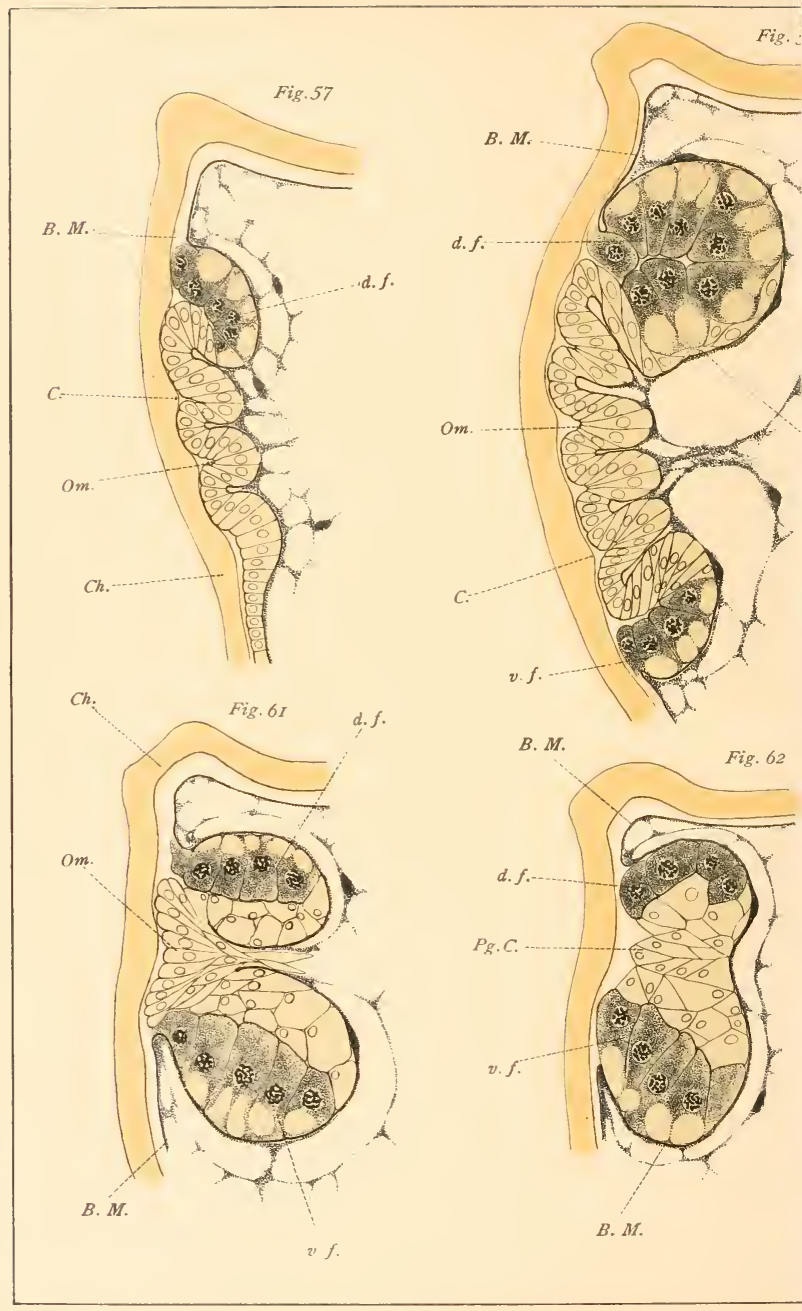


d. f.

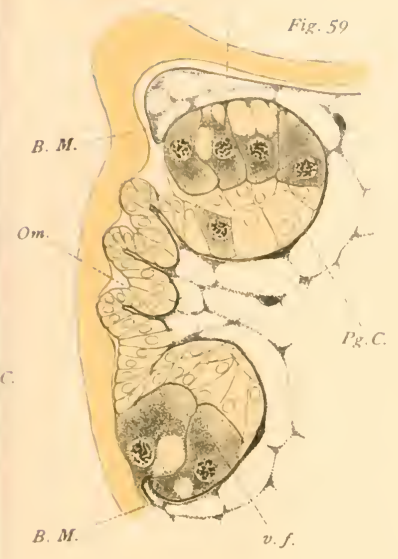

Ch.

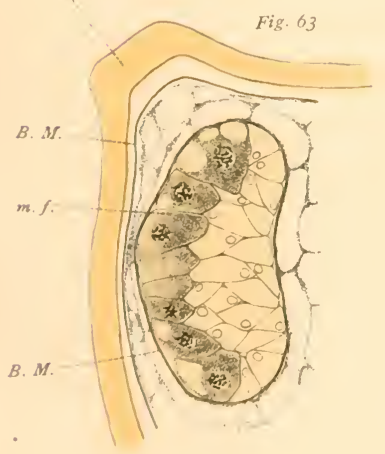

Ch.

Fig. $\sigma_{u}$
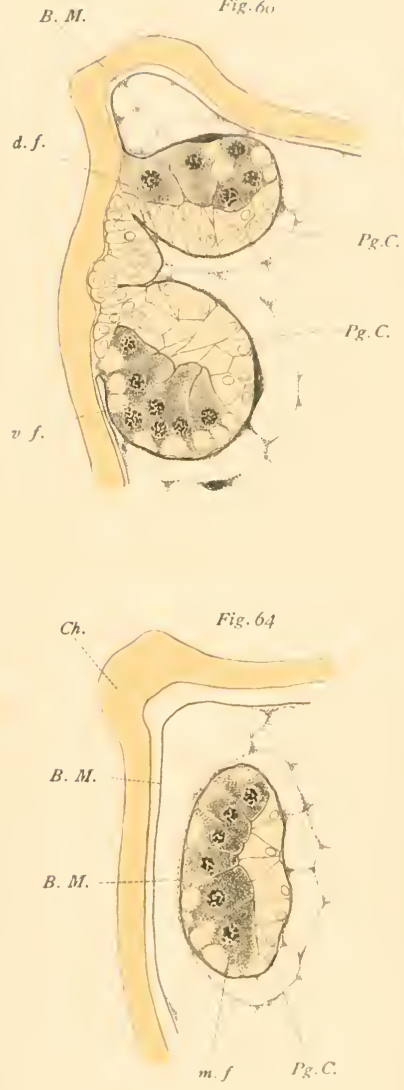


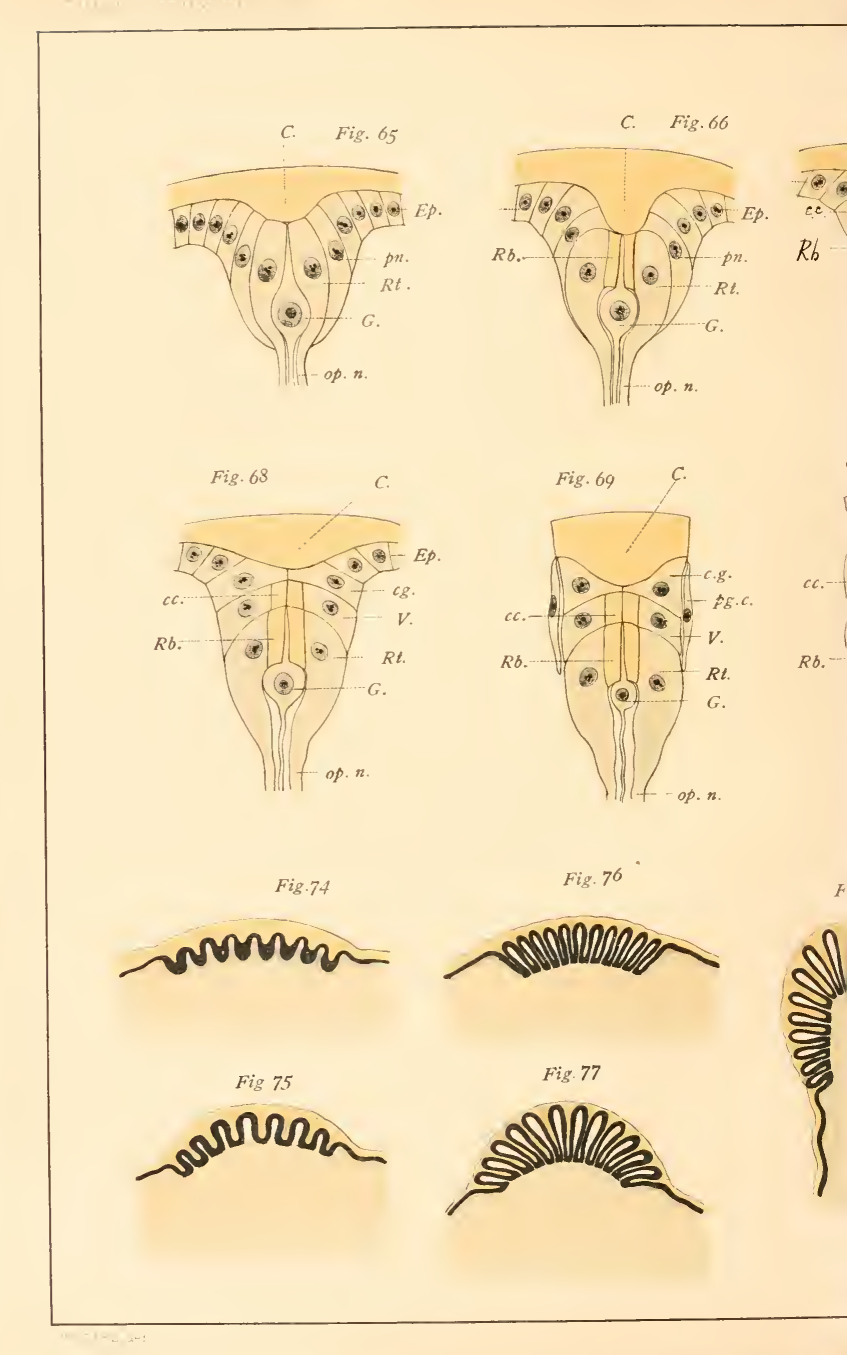




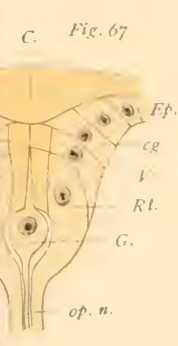

Fig $7^{\circ} \quad \therefore$

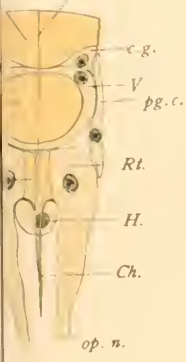

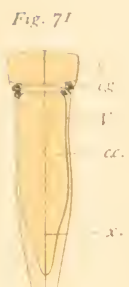

Fis. $7^{2}$

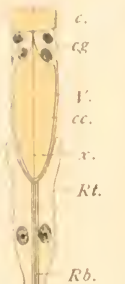

$$
\text { Fi: } 73
$$
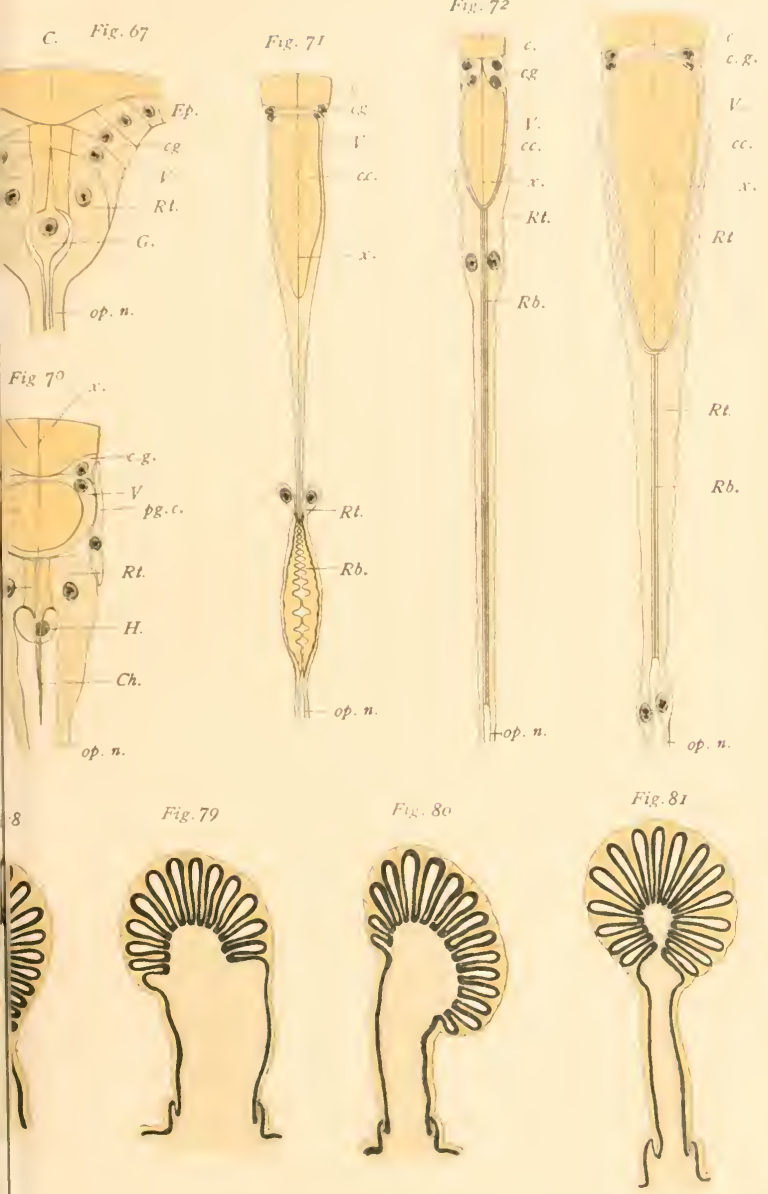


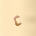








\section{.}








. 






$$
\text { , }
$$ 




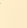




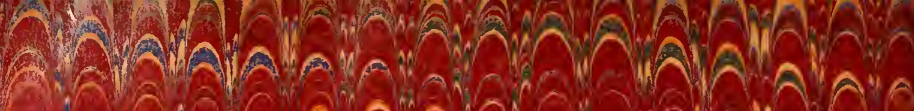

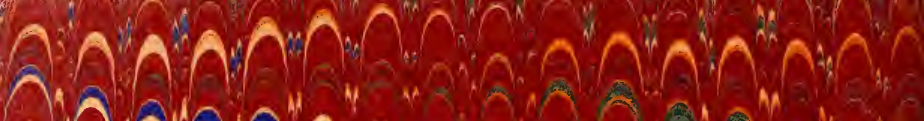

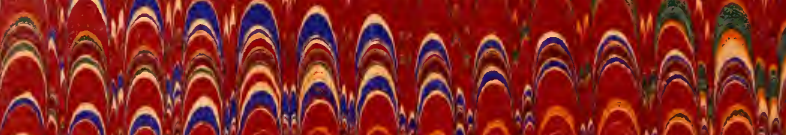
Q. N Nan

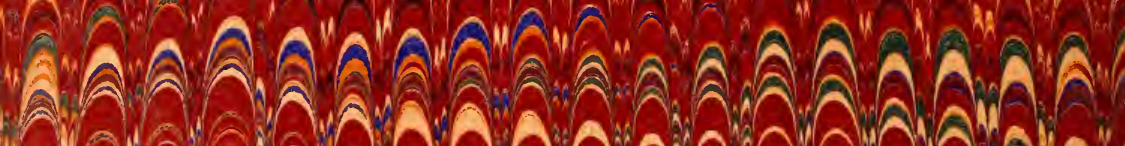
- *. A NAN A N N N"

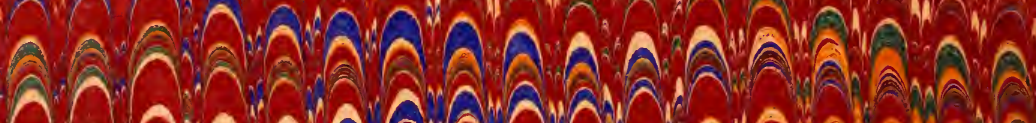

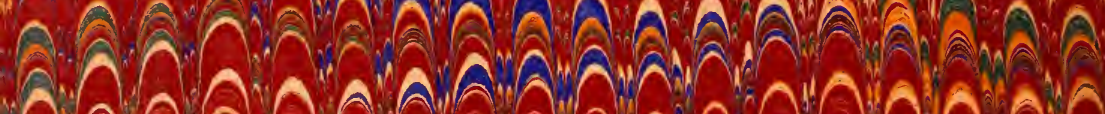
NA ANA ON N N A A A

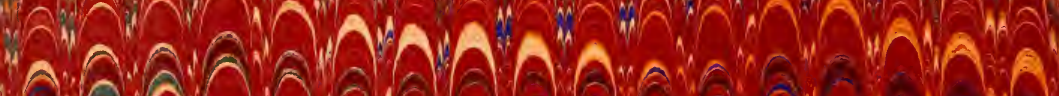
-2 ?

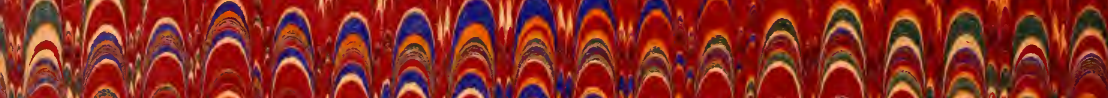

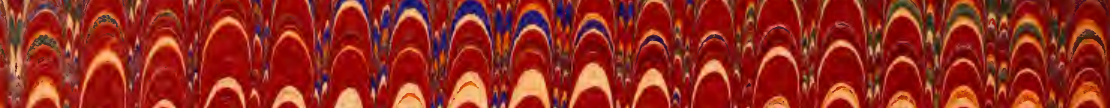
A A A A A N N A A

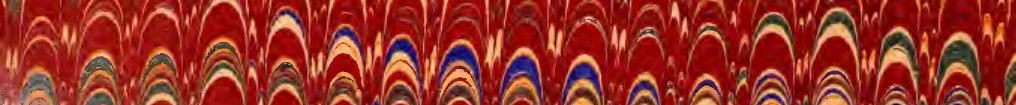
2 - 2 ล (5)

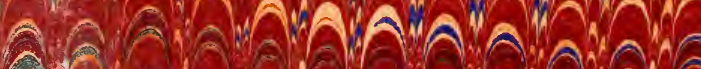
ล. 


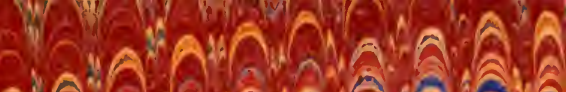
AMNAN P.

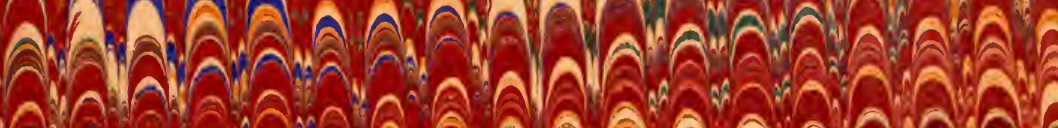
Ana

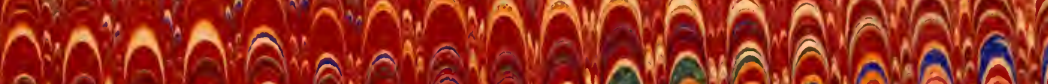

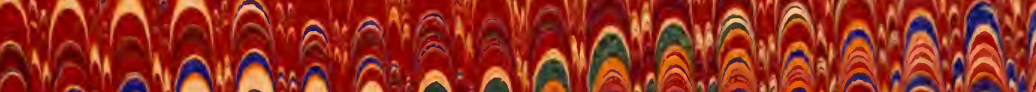

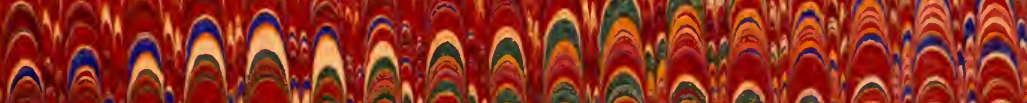

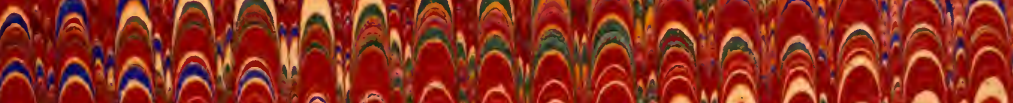
:

\section{A 0 ?}

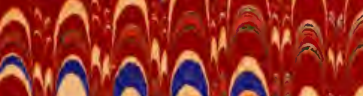

ล) A

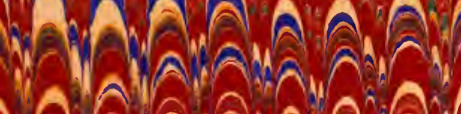

A 0

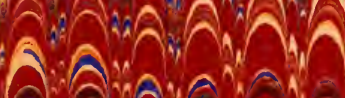

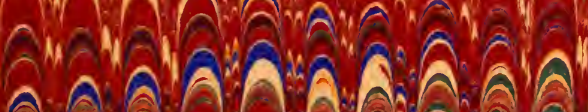

\section{A. 2} (2) and and ล. An. A

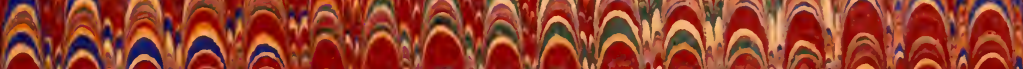




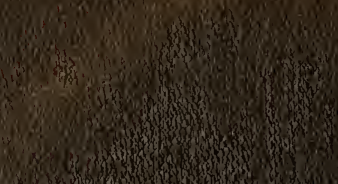

20

5.

16.5.

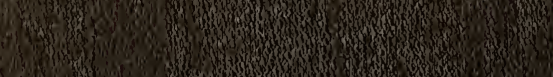

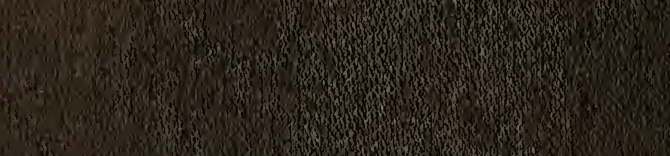

6.5.

Som

3.M.

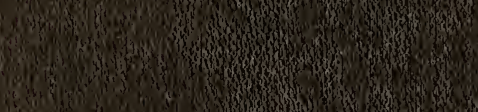

15.

S3)

(5) Din

4.

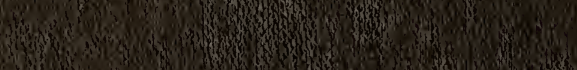

2. 1 .

65.

37.

1.

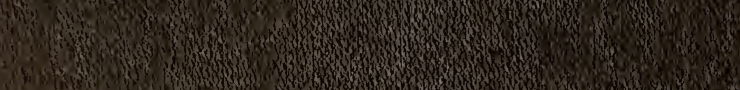

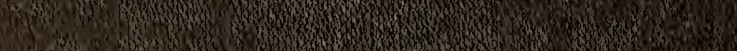

a

1.4.

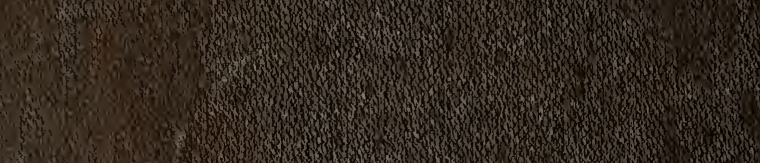
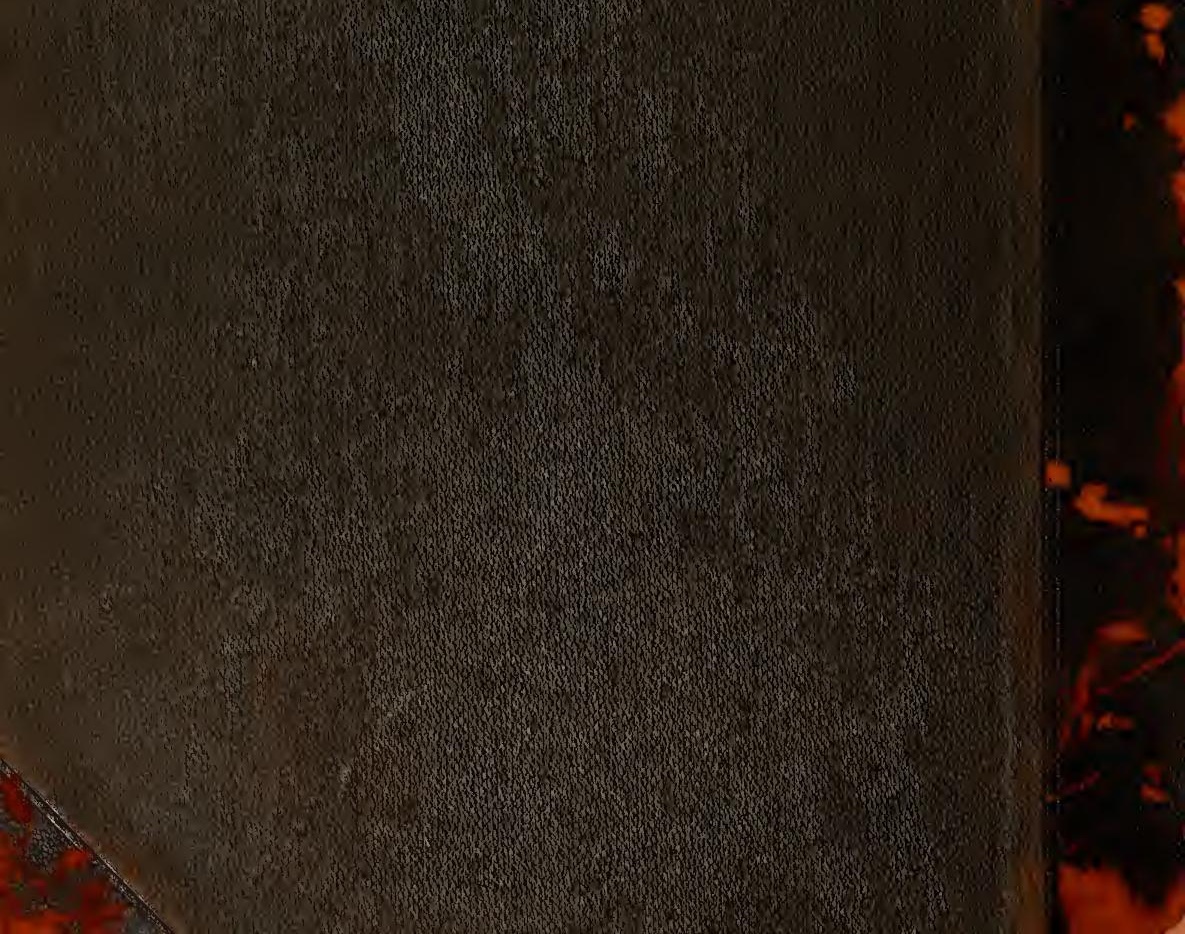

I. 